


\title{
The Unintended Consequences of Employer Credit Check Bans for Labor Markets
}

\author{
By Kristle R. CORTÉs, ANDREW Glover AND Murat TASCI*
}

May 18, 2020

\begin{abstract}
Over the last 15 years, 11 states have restricted employers' access to the credit reports of job applicants. We estimate that county-level job vacancies have fallen by 5.5 percent in occupations affected by these laws relative to exempt occupations in the same counties and national-level vacancies for the same occupations. Crosssectional heterogeneity suggests that employers use credit reports as signals of a worker's ability to perform the job: vacancies fall more in counties with a large share of subprime residents, while they fall less for occupations with other commonly available signals. Vacancies fall most for occupations involving routine tasks, suggesting that credit reports contain information relevant for these types of jobs.
\end{abstract}

JEL Codes: E24, E65, J23, J63

Keywords: vacancies, credit score, credit check

* Murat Tasci (Corresponding author): Federal Reserve Bank of Cleveland, 1455 East 6th Street, Cleveland, OH 44113 (murat.tasci@clev.frb.org); Kristle Romero Cortés: The University New South Wales, School of Banking and Finance, UNSW Business School, Sydney, NSW Australia 2052 (kristle.cortes@unsw.edu.au); Andrew Glover: Federal Reserve Bank of Kansas City, 1 Memorial Dr, Kansas City, MO 64113 (andrew.glover@kc.frb.org). The views expressed in this paper are those of the authors and not necessarily those of the Federal Reserve Bank of Cleveland or the Federal Reserve System. The authors would like to thank seminar participants at the Cleveland Federal Reserve Bank, University of Texas at Austin, University of Wisconsin - Madison, the Stata Empirical Microeconomics Conference, IESE Business School, UNSW Business School, Boston College Business School, Monash Business School, FIRS -Hong Kong, EFA- Mannheim, Philadelphia Federal Reserve Bank, Mitsui Finance Symposium, FIRN Banking, FIRN Byron Bay, University of Sydney and University of Tasmania. We would also like to thank our discussants, Yi Huang, Marieke Bos and Andres Liberman, Keke Song, Junhao Liu, as well as Mark Bils, Marika Cabral, Stefan Nagel, Victoria Ivashina, Philip Strahan, Erwan Quintin, Timothy Dunne, Ben Malin, Chris Nekarda, Jaromir Nosal, Orhun Sevinc, Anjan Thakor, Stephen Trejo, Dean Corbae, Didem Tuzemen, Insan Tunali, Kamil Yilmaz, Mehmet Yorukoglu, and Hakki Yazici for useful comments. We are indebted to Caitlin Trainer and George Nurisso for their excellent research assistance. 
"We want people who have bad credit to get good jobs. Then they are able to pay their bills and get the bad credit report removed from their records. Unfortunately, the overuse of credit reports takes you down when you are down.” $\quad$--Michael Barrett (State Senator, D-Lexington, MA).

\section{Introduction}

Over the last 20 years, credit reporting agencies have started marketing credit reports to employers to use in hiring. The three largest credit reporting agencies (Experian, Equifax, and TransUnion) currently offer the service, and a 2009 survey of human resource managers at Fortune 500 companies found that 60 percent of respondents used credit reports in at least some hiring decisions (Esen, Schmit, and Victor 2012). Additionally, a survey by the policy group Demos found that 10 percent of low- to medium-income workers claimed bad credit as a reason for being denied a job (Demos 2012).

In response to high unemployment and worsening credit conditions during the Great Recession, lawmakers sought to limit employer credit checks at the city, state, and national levels. When introducing and lobbying for these laws, many lawmakers voiced concerns that employer credit checks may create a poverty trap in which a person with bad credit cannot find a job and therefore cannot improve her credit. ${ }^{1}$ As of November 2019, 11 states have banned employer credit checks for at least some jobs, as seen in Figure 1. However, these bans have been implemented in a staggered way across the country, and states that have banned employer credit checks have exempted certain occupations that involve access to large amounts of money or sensitive information, such as Social Security numbers.

While banning employer credit checks may eliminate employment discrimination based on credit reports at the microeconomic level, restricting information about potential employees may also affect employers' expected profitability of posting a job vacancy and thereby affect job creation. To study this equilibrium effect, we estimate the change in vacancies at the county level for occupations affected by the law relative to those that are exempt in the same county and relative to the same occupations in counties without the ban. Formally, our empirical framework is a triple-

\footnotetext{
${ }^{1}$ Many state and national legislators have expressed support for employer credit check bans using similar language as Michael Barrett at the top of this page (Chen 2017). State senator Morgan Carroll of Colorado made the argument, "You can't pay your bills on time without an income" (Hughes 2012). Senator Elizabeth Warren has introduced national credit check ban legislation and said, "This is a point of basic fairness... people who get hit with hard economic blows end up getting squeezed out of the system" (Ellis 2013). Representative Maxine Waters of California has recently pushed for national legislation as well, saying "People who have been unemployed for an extended period of time, and whose credit standing has been damaged because they were unable to pay their bills, cannot secure a new job to end their financial distress because prospective employers conduct credit checks as part of an application process" (Maurer 2020).
} 
difference linear regression model: county-time fixed effects flexibly control for local labor market conditions and occupation-time fixed effects control for aggregate variation at the occupation level. We estimate that employer credit check bans have reduced equilibrium vacancies by 5.5 percent in affected occupations.

Economically, a 5.5 percent decline in vacancies for affected occupations is significant. For example, this decline is one fifth of the 26.2 percent decline of total vacancies in affected occupations during the Great Recession seen in Table 2b. We can also map our estimates to average unemployment duration for job seekers affected by employer credit check bans. Hall and Schulhofer-Wohl (2018) estimate that a 1\% fall in vacancies reduces the average job-finding rate by $0.53 \%$, holding unemployment constant. Using their elasticity, our estimated $5.5 \%$ decline in vacancies implies that an unemployed person searching for a job in an affected occupation would see her job-finding rate fall by 2.9 percent following the ban, all else equal. Assuming an average unemployment duration of 34.4 weeks (the national average in May 2014, when the last ban went into effect), this translates into approximately one extra week of unemployment on average. ${ }^{2}$

Our estimates identify the causal effect of employer credit check bans assuming that affected occupations would have otherwise followed the trajectory predicted by the same occupations in states without the ban and exempt occupations in the same county. While we cannot test this assumption directly, state laws have not referenced the relative labor market conditions for specific occupations when introducing employer credit check bans. Furthermore, exemptions appear to be made for reasons orthogonal to a given occupation's labor market at the time of the ban: states typically exempt occupations in which workers can readily embezzle from the employer, commit fraud, or steal from customers. ${ }^{3}$ Finally, we find no evidence of pre-ban divergence in vacancies between affected and exempt occupations, which supports the validity of our identification strategy.

Given the number of states that have already banned employer credit checks, our estimates provide a compelling reason for lawmakers to re-evaluate the efficacy of employer credit check bans. However, our estimates may also reveal the economic mechanisms through which workers' credit histories affect labor demand. We therefore analyze a simple theoretical model in which

\footnotetext{
${ }^{2}$ This calculation for the decline in the job finding rate holds unemployment constant, so is best thought of as an approximation to the short-run change (i.e. before the relevant stock of unemployed can adjust). The duration calculation approximates the average duration as the inverse of the job-finding rate.

${ }^{3}$ We have compiled each state's law in our online appendix, along with articles written around the time that many states passed employer credit check bans. We could not find any lawmaker or lobbyist who mentioned the relative strength of labor demand when exempting some occupations rather than others.
} 
credit reports are used to screen workers. The model predicts that employer credit check bans have larger effects in areas with more subprime workers and in occupations with fewer substitute signals. $^{4}$

These predictions motivate us to estimate heterogeneous effects of credit check bans. First, we find that vacancies fall more for affected occupations in counties with a large share of subprime residents, consistent with credit reports being a more valuable signal when labor markets are more adversely selected. ${ }^{5}$ Second, we find that vacancies decline more for occupations that employ workers with less than a college degree, consistent with employers coping with the loss of credit report information by substituting education as a signal when such information is available. Third, we find that state-level job-to-job flows rise in industries affected by bans, consistent with employers substituting current employment status as a signal of job readiness. Fourth, we find that vacancies decline more in occupations that involve routine tasks relative to those that involve nonroutine tasks, suggesting the information provided by credit reports is more relevant for routine jobs.

We focus on job vacancies for two reasons. First, firms control the number of vacancies posted, so they are an especially close proxy for the demand of unemployed workers. In contrast, other equilibrium outcomes, such as unemployment or job-finding rates, would also reflect changes in labor supply in response to employer credit checks. Second, we find our triple-difference model most convincing for causal inference and can assign exemption status to vacancies but not to other labor market variables. Nonetheless, we estimate difference-in-difference models using the unemployment, job-finding, and separation rates. Following an employee credit check ban, states experience higher unemployment and separation rates and lower job-finding rates. These estimates are qualitatively consistent with our vacancy findings, but we believe they are biased toward zero given our inability to differentiate by exposure to the ban. We also lose statistical precision when using state-level data.

\footnotetext{
4 These estimates also speak to recent theoretical work on the interaction between credit and labor markets. Donaldson, Piacentino, and Thakor (forthcoming) posit a theory in which debt overhang suppresses vacancies by raising workers' reservation wages. Most directly related to our policy-based identification strategy is Corbae and Glover (2018), who develop a screening model in which employers use credit reports in hiring because repayment rates are positively correlated with an unobservable component of worker productivity.

${ }^{5}$ Our baseline proxy for county-level credit quality is the fraction of subprime residents because the credit report sold to employers omits scores. We assume that an employer can tell if a credit report is broadly good (prime) but cannot compute the precise risk score. However, we present results using other proxies of county-level credit conditions.
} 
We use data on both labor and credit markets because we are interested in the interaction between the two. Our primary labor market variable is county-level vacancies by occupation from the Conference Board's Help Wanted OnLine (HWOL) panel. In some of the empirical specifications, we also use state and industry job-to-job flows are from the U.S. Census Longitudinal EmployerHousehold Dynamics panel. We create the series of state-level employer credit check bans and occupational exemptions from the relevant legislation record, as summarized in Table 1. We measure a county's share of subprime residents using the Federal Reserve Bank of New York's Consumer Credit Panel/Equifax (FRBNY CCP/Equifax). ${ }^{6}$

Section 2 reviews some recent literature. Section 3 provides a simple screening model of vacancy creation to motivate our empirical specifications. Section 4 discusses our data in detail. Section 5 presents our baseline empirical estimates, and Section 6 explores the mechanism using county and occupational heterogeneity in exposure to the ban. Section 7 presents robustness exercises and Section 8 concludes.

\section{Related Literature}

Several studies analyze the effects of employer credit checks on labor market outcomes. To our knowledge, ours is the first to study the effect of employer credit check bans on vacancy creation, which allows us to analyze the equilibrium response of employers to employer credit check bans and to leverage the exemption status of occupations for identification. We are among the first to study the effect of these laws on labor markets in general, although two recent papers by Ballance, Clifford, and Shoag (2016) and Bartik and Nelson (2019) are closely related. While they consider different outcome measures and implement different empirical strategies, these studies also find that employer credit check bans have negative labor market effects on at least some workers, such as black job seekers. On the other hand, Friedberg, Hynes, and Pattison (2018) find that people reporting financial difficulties enjoy higher job-finding rates following a ban, which is consistent with more pooling following employer credit check bans.

Our paper is also related to several recent papers that study the use of credit report information in labor markets in general. Bos, Breza, and Liberman (2018) find that a regulatory change in

\footnotetext{
6 The Federal Reserve Bank of New York's Consumer Credit Panel/Equifax data are a subset of credit data maintained by Equifax, one of the large credit reporting agencies. The data are from a 5 percent sample of all individual credit records that Equifax maintains.
} 
Sweden that removed negative information from individual credit reports lead to an increase in employment rates for those who were affected. Herkenhoff, Phillips, and Cohen-Cole (2016) and Dobbie, et al. (2019) study the response of employment and earnings to a default flag from the credit reports of Americans. These studies compare labor market outcomes for Chapter 13 bankruptcy filers to Chapter 7 filers (who's flag remains for three years longer). They estimate that the removal of a Chapter 13 default flag leads to positive, but small, increase in the probability of a person being employed in a given year. These studies are likely to identify labor supply responses to credit market changes, rather than labor demand, because the U.S. legal code restricts employers from discriminating against workers who have formally filed for bankruptcy (11 U.S.C. Sec 525(b), 2012). ${ }^{7}$

\section{Screening and Vacancy Creation}

We now illustrate how our empirical results are motivated and consistent with employers using credit reports to screen job applicants. The model is a simplified version of Corbae and Glover (2018)'s dynamic theory. We initially assume that the credit reports of job seekers are observed by prospective employers, who can judge whether a given report constitutes "prime" or "subprime" credit. ${ }^{8}$ A worker with prime credit generates discounted expected profits of $\prod$, while a subprime worker $\pi<\prod \cdot{ }^{9}$ However, the employer can mitigate some costs of employing a subprime worker, thereby raising the discounted expected profits from $\pi$ to $\pi+\mu$, where $\mu$ is the net gain from performing the mitigation. The mitigating action could be refusing to hire the person (i.e. if $\pi<0$, then $\mu=-\pi$ ), but could also include training or mentoring her, in which case $\mu$ would be the expected gains net of any costs incurred to improve the worker's match with the job.

Denote the share of people with subprime credit in region $i$ as $\mathrm{F}_{\mathrm{i}}$ and the number of unemployed job seekers as $u$. If $k$ is the cost of posting a vacancy (denoted $v$ ), then the labor market tightness $\left(\theta=\frac{v}{u}\right)$ rises until the expected profits from posting a job is equal to the cost:

\footnotetext{
${ }^{7}$ The code forbids public employers from discriminating against the bankrupt in terms of both hiring or firing. It forbids discrimination against current employees of the private sector, but this was only clarified in 2011 after a multyear lawsuit (Myers v. Toojay Management Corporation, 2011), so private-sector firms may have avoided discriminating based on bankruptcy filings to avoid potential litigation before then.

${ }^{8}$ This assumption is consistent with the products marketed to employers. These reports list credit market histories, but do not provide a risk score, as would be included in a report sold to lenders.

${ }^{9}$ Our assumption that subprime workers generate lower expected discounted profits is foreshadowing our estimate of a decline in vacancies following the bans. Of course, one could instead formulate a theory in which subprime workers are more profitable (they may accept lower wages out of necessity, for example), but this would be inconsistent with our empirical findings.
} 


$$
q\left(\theta_{i}\right)\left[F_{i}(\pi+\mu)+\left(1-F_{i}\right) \Pi\right]=k,
$$

where the function $q$ gives the probability of a firm matching with a worker for a given tightness $\theta$. The idea of frictional matching means that a given firm finds it harder to match in a tight labor market, so that $q^{\prime}\left(\theta_{i}\right)<0$.

What happens when firms are forbidden checking credit reports? Suppose that fraction $\epsilon$ of subprime job seekers carry an alternative signal that is still available after the ban (college transcripts, for example, or current employment status at another job). Then the new market tightness, $\theta^{\prime}$, satisfies ${ }^{10}$

$$
q\left(\theta_{i}^{\prime}\right)\left[F_{i} \in(\pi+\mu)+\left(1-F_{i}\right) \Pi\right]=k .
$$

Equation (2) can then be approximated around the tightness from equation (1), which has the same number of job seekers in the denominator, to express the change in vacancies due to eliminating employer credit checks as

$$
\log \left(v_{i}^{\prime}\right)-\log \left(v_{i}\right)=\frac{q\left(\theta_{i}\right)}{q^{\prime}\left(\theta_{i}\right) \theta_{i}} \times \frac{F_{i}}{F_{i} \pi+\left(1-F_{i}\right) \Pi} \times(1-\epsilon) \times \mu .
$$

Equation (3) formalizes the hypothesis that vacancies should fall in response to a ban on employer credit checks if credit reports are used to screen workers, as well as the sources of occupational and county heterogeneity that matter for the magnitude of the effect. The first term, in red, is negative while the remaining terms are positive, so vacancies are expected to decline post ban. The second term, in blue, indicates that the exposure of vacancies to the ban is increasing in the share of subprime residents in a county. The third term, in green, measures the availability of substitute signals: the closer $\epsilon$ is to one, the smaller effect of employer credit check bans. Finally, the fourth term, in purple, is the amount gained from observing a new hire's credit report: the larger it is, the more vacancies are expected to decline following the ban.

\section{Data}

Table 1 details the timeline of changes in the law across states and Figure 1 maps the states that have laws in effect as of April 2017. Throughout our empirical analysis, we focus on the period 2005:Q1 through 2016:Q4. We use the date at which the law became enforceable to code our treatment flag, with the convention that dates falling within a quarter are coded as the beginning

\footnotetext{
${ }^{10} \mathrm{We}$ assume that the share of subprime job-seekers is small enough that the firm chooses to hire without mitigation. Of course, the firm may prefer to mitigate for all workers if the share of subprime workers is near 100\%. Empirically, the median county is less than $26 \%$ subprime and $95 \%$ of counties are less than $47 \%$ subprime.
} 
of that quarter ( 8 of 11 states began enforcing their bans at the start of a quarter). The resulting summary statistics for this flag are seen in the first four columns of the panel a) in Table 2. More than 10 percent of counties are affected by the credit check bans at the end of our sample period (out of 3,137 ) covering 26.5 percent of the US labor force.

\section{A. Labor Market Data}

Our principal labor market outcome is the county-level vacancy (job opening) data reported by the Conference Board (2017) as part of its Help Wanted OnLine (HWOL) data series. HWOL provides a monthly snapshot of labor demand at detailed geographical (state, metropolitan statistical area, and county) and occupational (six-digit SOC and eight-digit $\mathrm{O} * \mathrm{Net}$ ) levels since May 2005. ${ }^{11}$ For the period in question, HWOL represents the bulk of the advertised job openings, as print advertising declined in importance. ${ }^{12}$ We use county-level data for every state and Washington D.C., except for Delaware, which we omit because their credit check ban only applies to public employers.

HWOL covers roughly 16,000 online job boards, including corporate job boards, and aims to measure unique vacancies by using a sophisticated deduplication algorithm that identifies unique advertised vacancies based on several ad characteristics such as company name, job title/description, city, or state. HWOL is not the only source of data on job openings, though. The Bureau of Labor Statistics (BLS) publishes nationally representative data, the Job Openings and Labor Turnover Survey (JOLTS), which also measures vacancies. However, HWOL's detailed geographic- and occupation-level coverage makes it uniquely attractive for our analysis. ${ }^{13}$

Specifically, our identification strategy relies on occupational heterogeneity in exposure to employer credit check bans within a given county. We assign exemption status by state and twodigit SOC code as outlined in Table $1 .{ }^{14}$ The resulting sample will have observations on vacancies

${ }^{11}$ For a detailed description of the measurement concepts and data collection methodology, please see Conference Board (2017). The Conference Board Help Wanted OnLine ${ }^{\circledR}$ (HWOL) at https://www.conferenceboard.org/data/helpwantedonline.cfm.

${ }^{12}$ In fact, HWOL started as a replacement for the Conference Board's Help-Wanted Advertising Index of print advertising.

13 JOLTS' publicly available data files do not have more detailed coverage than census regions and lack any information on occupational characteristics. For most of the sample period, the general patterns reported in JOLTS and HWOL are reasonably close to each other. See, for instance, the relevant discussion in Sahin, et al. (2014). Researchers identified a recent diversion between vacancy measures across these two sources, one that is attributed to a change in pricing on several online job boards (Cajner and Ratner, 2016). To the extent that fixed effects in our empirical specifications absorb these pricing changes, our results will be immune to significant bias by relying on HWOL.

${ }^{14}$ Exemptions could be assigned using six-digit SOC codes instead of two-digit. However, this requires more judgment calls and leads to many county-quarter observations with zero vacancies. Finally, using six-digit SOC codes 
at the county level for up to 23 different two-digit occupations. Panel b) in Table 2 summarizes the data on vacancies. On average, affected occupations constitute a larger sample and have consistently stayed higher than the exempt occupations in levels. Both groups of vacancies present procyclicality, experiencing substantial declines on average during the Great Recession. We also use the occupational coding of HWOL when estimating the differential effects of bans by occupational education requirements and task composition, which we discuss in each relevant section.

Our baseline estimates only identify the effect of bans on affected occupations relative to exempt occupations, but not the levels of each. In order to estimate the effects on exempt and affected occupations separately while retaining granular fixed effects, we use counties along the borders of adjacent states as one of them enacts a ban. The resulting sample contains vacancies in each occupation for each contiguous county pair in which one county eventually passes an employer credit check ban. Summary statistics for this sample are reported in Table $3 .{ }^{15}$ Comparing the summary statistics for exempt and affected groups in the full sample (in Table 2) and those in the adjacent county sample shows how similar the samples look. We are reassured that our sample of adjacent counties resembles the nation as a whole.

We prefer vacancies as our proxy for labor demand not only because they are measured at the occupational level but also because employers control vacancies directly, making them one step of equilibrium interaction to desired labor demand. However, we also estimate the response of other labor market variables: the unemployment, job-finding, separation, and job-to-job transition rates following a ban. For unemployment, we use county-level data reported by the Bureau of Labor Statistics' LAUS program. ${ }^{16}$ The job-finding and separation rates are computed from CPS microdata at the state level. Since respondents in the survey are interviewed repeatedly for certain

limits the replicability of our main results because the Conference Board's six-digit HWOL data have stricter access restrictions than the two-digit data.

${ }^{15}$ We thank Alan Collard-Wexler for publicly posting his data set of US counties and their neighbors, which we used to create our contiguous county sample. Collard-Wexler's data is available at https://sites.duke.edu/collardwexler/data/.

${ }^{16} \mathrm{We}$ also have county-level observations for employment and labor force through LAUS. All of these estimates for counties are produced through a statistical approach that also uses data from several sources, including the CPS, the CES program, state UI systems, and the Census Bureau's American Community Survey (ACS), to create estimates that are adjusted to the statewide measures of employment and unemployment. Hence, the data from LAUS is subject to some imputations for certain states. 
months, one can create a panel from the observed transitions of workers. ${ }^{17}$ Finally, the job-to-job flow rate is reported at the state level by the CPS LEHD program.

\section{B. Credit Market Data}

The FRBNY CCP/Equifax panel provides detailed quarterly data from Equifax on a panel of US consumers and includes Equifax risk scores (credit scores) and other data on consumer credit reports. We aggregate individual credit information to estimate the effect of the ban as a function of the subprime share within a county. The distribution of subprime borrowers across counties and over time is found in Table 4. For this paper, we follow the literature and assume that the critical level for being subprime is an Equifax risk score of 620. Over the sample period we analyze, the average fraction of subprime borrowers within a county was 27 percent, declining from 29 percent to 25 percent over time.

There is substantial variation across counties in our sample: The share of subprime residents for a county in the $95^{\text {th }}$ percentile is over 45 percent, while the bottom quartile's share is only 20 percent. Within a county, there is also variation in this share over time, as shown in Figure 2. This figure shows deciles of the maximal quarter-on-quarter change in each county's subprime rate, relative to the 2005 average rate. The top decile of the variation in subprime rates has counties that experienced changes of 12 percent of the 2005 average in at least one quarter and even the least variable decile saw quarterly changes of 2.6 percent at some point.

\section{Results}

We use a county-level panel with labor market data and an individual-level credit panel to test the effects of the employer credit check bans. We primarily estimate the effect on job creation (measured by the number of help-wanted ads posted online) using county-level HWOL data.

\section{A. Effects of the Credit Check Bans on Job Posting}

Our preferred empirical model is a triple-difference regression of the form:

$$
V_{i, o, t}=\alpha_{i, o}+\mu_{o, t}+\gamma_{i, t}+\beta \text { Ban }_{i, t} * \text { Affected }_{i, o}+\varepsilon_{i, o, t},
$$

\footnotetext{
${ }^{17}$ Each respondent is interviewed for four months initially and then leaves the survey for eight months. They are interviewed again for four more months. For any given month, about 70 percent of the survey respondents are observed consecutively, allowing us to create a panel to measure average job-finding and separation hazards. Unfortunately, because of the size of the CPS and the number of transitions, we cannot obtain estimates for more granular levels than state. We follow Nekarda (2009) to minimize the bias induced by mobility.
} 
where the variable $V_{i, o, t}$ is the $\log$ of vacancies posted in county $i$ at date $t$ for occupation $o$, and the variables $B_{i, t}$ and Affected $_{i, o}$ are indicator variables. The ban indicator is equal to one only for those dates when county $i$ is subject to a ban and the "Affected" indicator is one only for occupations that are subject to the ban in county $i$. The parameter of interest is $\beta$ and $\alpha_{i, o}$ is a countyoccupation fixed effect, $\gamma_{i, t}$ is a county-time fixed effect (measured quarterly), and $\mu_{\mathrm{o}, \mathrm{t}}$ is an occupation-time fixed effect.

The coefficient of interest, $\beta$, is identified from the growth in vacancies for affected occupations around the time that a state enacts a ban, relative to exempt occupations in that state and to growth in national vacancies in the affected occupation. The estimated coefficient for vacancies is found in column (1) of Table 5: It is statistically significant and economically large, implying a 5.5 percent decline in vacancies in affected occupations after the ban goes into effect. ${ }^{18}$

We have attempted to saturate the model with granular fixed effects in order to control for unobserved heterogeneity in the labor markets for each occupation in each county. Our baseline allows for arbitrary unobserved occupational heterogeneity at the national level, but we can dig deeper by restricting attention to contiguous counties along state borders. In column (2) of Table 5 we estimate Equation (4) using the contiguous county sample, which allows us to replace the occupation-by-time fixed effects with occupation-by-contiguous-county-pair-by-time fixed effects. With this specification, we estimate a $6.8 \%$ decline in vacancies for affected occupations in ban counties, relative to exempt occupations in the same county and relative to the same occupation in neighboring counties without the ban. Our baseline estimate is therefore conservative to controlling for even more granular unobservable labor market shocks.

We have used the contiguous county design to control for extremely local unobservable heterogeneity in our triple-difference regression model, but it is also commonly used to identify policy effects when there is no intra-county measure of treatment (our specification is closest to Dube, et al. (2010)). Following that literature, we estimate the response of exempt occupations to a ban in the contiguous county sample separately from that of affected occupations. This is a quasiplacebo test, since we expect any causal effect of bans on these occupations to be through indirect spillovers or misclassification. We therefore estimate the regression

$$
V_{i, o, p, t}=\alpha_{i, o}+\gamma_{o, p, t}+\beta_{1} \text { Ban }_{i, t}+\beta_{2} \text { Ban }_{i, t} * \text { Affected }_{i, o}+\varepsilon_{i, o, p, t},
$$

18 There are 914,694 occupation-county-quarters with zero posted vacancies, which are dropped with the $\log$ transformation. In Section 7 we show that the coefficients are similar if we use the inverse hyperbolic sine transformation, which keeps these observations. 
where $\gamma_{o, p, t}$ is the fixed effect that links a given occupation across county pairs in a given quarter. The coefficient $\beta_{1}$ is identified from the difference in exempt-occupation vacancies in treated counties as the ban goes into effect, relative to their neighboring counties in untreated states, and is expected to be near zero. The coefficient $\beta_{2}$ is then identified by the excess change in affected occupations relative to exempt occupations, again in treated states relative to their neighbors as the ban goes into effect, and is expected to be significantly negative.

Column (3) in Table 5 presents our estimates from this specification. We estimate a significantly negative $\beta_{2}$, while $\beta_{1}$ is insignificantly different from zero, which indicates that the entire post-ban decline in vacancies occurs in affected occupations. Column (4) adds a control for a county's unemployment rate to equation (2), which captures some additional variation beyond county-pairoccupation fixed effects, but the coefficients of interest are similar to column (3), both in magnitude and statistical significance.

\section{B. Policy Endogeneity and Testing for Pre-Ban Divergence}

Many legislators were concerned about weak labor markets when they proposed employer credit check bans, which raises classic endogeneity concerns if we were to estimate the effect of employer credit check bans on overall vacancies. However, legislators did not discuss relative labor market conditions to determine which types of jobs are exempt from the bans. Rather, the jobs that can continue to check applicants' credit reports are those in which employees have a greater scope for embezzlement, fraud, or theft. We therefore interpret the decline in vacancies for affected occupations relative to exempt occupations as being caused by the ban, rather than bans being imposed in response to the relative decline in vacancies for affected occupations.

We would still overstate the effect of bans on vacancies if affected and exempt occupations were diverging leading up to the bans. We therefore estimate a distributed-lags specification of equation (1) that captures vacancy dynamics around the implementation of bans. This approach has been found to be especially useful for studying the effects of staggered implementation of the treatment (policy change) across different jurisdictions with a difference-in-difference identification strategy. ${ }^{19}$

We estimate the following equation:

\footnotetext{
${ }^{19}$ Some examples include Bertrand and Mullainathan (1999 and 2003) in the context of anti-takeover legislation and Meer and West (2016) in the study of minimum wage legislation.
} 


$$
\text { (6) } V_{i, o, t}=\alpha_{i, o}+\gamma_{i, t}+\mu_{o, t}+\sum_{j=-4}^{5} \beta_{j} \text { Ban }_{i, t+j} * \text { Affected }_{i, o}+\varepsilon_{i, o, t},
$$

where the variable $B a n_{i, t-j}$ equals one if county $i$ implements an employer credit check ban at date $\mathrm{t}-\mathrm{j}$ and zero otherwise, for $\mathrm{j}=-4$ through 4 , while $\operatorname{Ban}_{i, t+5}$ remains equal to one for all dates more than four quarters after the ban goes into effect; the coefficients $\beta_{-4}$ through $\beta_{5}$ therefore identify the difference between affected and exempt occupations relative to this difference a year plus before the ban. In this regression, a pre-ban divergence in vacancies between affected and exempt occupations manifests as significantly negative values of $\beta=4$ through $\beta_{0}$.

As reported in Table 6 and illustrated in Figure 3, $\beta_{-3}$ through $\beta_{0}$ are insignificant and small, while $\beta_{-4}$ is significantly positive: affected occupations do not have significantly fewer vacancies before the ban than do exempt occupations. Following the ban, the coefficients become both economically and statistically negative within two quarters and remain so, even beyond a year after the ban is implemented, which is captured by the coefficient $\beta_{5}$. The long run (beyond one year) is close to our baseline estimate and significantly negative at the 10 percent level.

\section{Effects on Other Labor Market Variables}

We prefer vacancies as our labor market outcome because it is most directly related to labor demand and we can leverage occupational variation in ban coverage to estimate our tripledifference specification, but policymakers may be more concerned with other labor market variables, such as the unemployment rate, job-finding rate, or job-separation rate. Furthermore, these aggregates are determined jointly in equilibrium, and so they provide a holistic view of labor market changes following the ban. We therefore estimate a difference-in-difference model for alternative labor market outcomes at both the state and the county levels, though we emphasize that these variables cannot be interacted with occupational exposure to the ban, which may attenuate the estimated treatment effects.

In Table 7, we report how other labor market aggregates change following the introduction of employer credit check bans. Columns (1) and (4) use county-level data on the unemployment rate and job finding rates. ${ }^{20}$ The unemployment rate (column (1)) increases by 1.2 percent and the job

\footnotetext{
${ }^{20} \mathrm{We}$ are able to calculate county-level job finding rates using data from unemployment insurance claims following the algorithm described in Hagedorn, Karahan, Manovskii, and Mitman (2019). We thank Fatih Karahan for providing this data to us. This data includes number of claimants and final payments at the county level in the regular state unemployment insurance program between 2005 and 2012. This data is not subject to imputation and depends on administrative records. The data does not cover our entire sample period, thereby giving us relatively fewer observations compared to our baseline.
} 
finding rate falls by 15 percent, but only the latter is significant at the $10 \%$ level. Columns (2) and (3) use state level separation and job finding rates from the CPS. While neither estimate is statistically significant, the point estimates indicate a rise in the separation rate and a decline in the job finding rate. Although neither is statistically significant, the point estimates are consistent with the signaling theory and with our estimated decline in vacancies for affected occupations. Thus, we think the results with additional labor market outcomes presented in Table 7 broadly support our main point in the paper. Lack of statistical significance in some of these estimates might be due to data limitations and coverage. LAUS data includes some imputations and CPS data can only provide state level aggregates, whereas information from UI claims does not cover some of the sample period we use for the vacancy data.

\section{Mechanism}

We now use occupational heterogeneity in the value of employer credit checks as signals to explore the mechanisms through which bans affect labor demand. First, we estimate larger postban declines in vacancies in counties with a large share of subprime residents. This is consistent with credit reports being used to screen job applicants, since their informative value would be greater if the pool of unemployed was more adversely selected in the first place.

Second, we test the effect of alternative signals on the effect of employer credit check bans. We do this in two ways. For vacancies, we allow the effect of bans to differ by the education level of workers typically employed in a given occupation. We find larger declines in occupations that employ workers with less education, a finding consistent with employer credit checks being particularly useful screening devices when other signals, such as information on college transcripts, are less readily available. We then estimate the effect of bans on job-to-job transition rates by occupational exemption status. Contrary to the case with vacancies, we find that job-tojob flows rise in occupations affected by the ban relative to those that are exempt, consistent with employment itself being an alternative signal to the credit report.

Finally, we explore what information employers might value from credit reports by estimating the effect of bans on jobs that involve routine tasks relative to those that involve nonroutine tasks. We estimate much larger declines in vacancies for jobs with routine tasks, a finding consistent with credit reports being informative about soft skills. These reasons align with the reasons that human resource managers report for using credit reports, which include preventing theft, reducing 
liability for negligent hiring, and assessing the overall trustworthiness of job applicants (Esen, Schmit, and Victor 2012).

\section{A. Heterogeneous Effects by County-Level Credit Market Conditions}

If employers prefer workers with good credit, then Equation (3) suggested that the exposure of vacancies to employer credit check bans is increasing in the share of subprime job-seekers. We therefore scale the independent variable by the share of subprime residents in county $i$ in 2005 , which is the first year of that credit panel data is available (and two years before the first employer credit check ban was implemented). ${ }^{21}$ The regression is given by

$$
V_{i, o, t}=\alpha_{i, o}+\gamma_{i, t}+\mu_{o, t}+\beta \text { Ban }_{i, t} * \text { Subprime }_{i} * \text { Affected }_{i, o}+\varepsilon_{i, o, t} .
$$

Column (1) of Table 8 reports our estimate of a higher county-level subprime fraction on vacancies for occupations affected by the ban. This effect is negative and strongly significant. The range of county subprime shares in Table 4 gives context for this estimate: The interquartile difference is 15 percentage points. Therefore, as a state bans employer credit checks, vacancies in affected occupations in a county in the $75^{\text {th }}$ percentile (which has a 34 percent subprime rate) would decline by 3.5 percent more than would vacancies in affected occupations in a county in the 25 th percentile (where 19 percent of residents are subprime).

The larger decline in vacancies in affected occupations in counties with more subprime workers is consistent with a theory of credit reports as signals, which are more valuable when the labor market is more adversely selected. From a policy perspective, the effects are worse for the areas for which legislators have professed concern when implementing bans, suggesting that these consequences truly are unintended.

The theory in Section 3 lead us to use the share of subprime residents as a measure of countylevel exposure to credit check bans. Of course, the amount of information provided by a credit report also depends on how much heterogeneity there is in the first place. In the extreme case, if everybody in a county had subprime credit, and if all employers knew this, then credit reports would not provide useful signals. We do not believe that this is a concern in practice, because most of our counties have subprime shares between 19 and 50 percent. Nonetheless, our estimates are robust to using cross-sectional measures of credit score dispersion to proxy for a county's exposure to credit check bans. This can be seen in the second and third columns of table 9, which interact

\footnotetext{
${ }^{21}$ We think keeping the subprime fraction variable at its 2005 levels also insulates it from the cyclical changes that occurred over the next several years in the data due to changing financial conditions. Nevertheless, in an earlier version of this paper, we used the current quarter subprime fraction and found similar results.
} 
the ban with a county's standard deviation and 90/10 ratio of credit scores (which we scale by the cross-sectional standard deviation of each measure). Each coefficient is significantly negative: affected vacancies decline more in counties that have larger cross-sectional standard deviations of risk scores or $90 / 10$ ratios of risk scores.

\section{B. Heterogeneous Effects by Occupational Skill Requirements}

If employers are restricted from using credit reports as signals of a worker's suitability to their jobs, then we expect them to use other available observables in the hiring process. Therefore, occupations in which other signals are common should respond less to employer credit check bans than those with few alternatives. We test this prediction using college education, which is itself a classic signal of unobservable worker ability (Spence 1978), but also provides additional signals such as the university attended and grades earned by the applicant.

The Conference Board's HWOL data allow us to map a subset of the occupational data into an education code that matches with the predominant education level for workers in that occupation. This information is not necessarily listed in the ad but is assigned based on the occupational coding using BLS mapping. ${ }^{22}$ The HWOL data aggregates vacancies in each county into eight educational groupings. Based on this categorization, 37 percent of all vacancies posted were in occupations associated with a college education or higher.

Since the educational groupings do not correspond to two-digit SOC codes, we cannot use exemption status as a source of variation that interacts with education. Instead, we maintain a triple-difference regression design by estimating the effect of vacancies in low-skill jobs relative to high-skill following the introduction of a ban. We estimate

$$
V_{i, e, t}=\alpha_{i, e}+\gamma_{i, t}+\mu_{e, t}+\beta \text { Ban }_{i, t} * \text { NoCollege }_{e}+\varepsilon_{i, e, t},
$$

where the indicator variable NoCollege $_{e}$ equals one for educational grouping $e$ if it typically employs workers with less than a college education and zero otherwise.

Column (2) of Table 8 reports our estimate of $\beta=-0.146$ from the above regression, which is significant at the 10 percent level. This is consistent with low-education jobs valuing credit reports as signals of unobservable worker profitability, relative to high-education jobs where signals related to education may be available (such as the college attended or GPA).

\footnotetext{
${ }^{22}$ The BLS assigns a typical level of education needed for entry into an occupation and has eight different categories. A detailed description of the categories can be found here:

https://www.bls.gov/emp/documentation/education/tech.htm.
} 


\section{State-Level Job-to-Job Flows}

Another signal of workers' unobservable ability is their employment history. For example, Kroft, Lange, and Notowidigdo (2013) perform a field experiment and find that unemployment duration has a strong negative effect on callback rates, a finding that Jarosch and Philossoph (2018) rationalize in a signaling model of frictional labor markets under adverse selection. Following this literature, we expect current employment to be a positive signal of a worker's suitability for other jobs, so employers may look to poach more frequently if they are restricted from using credit reports to screen amongst unemployed applicants.

To test this idea, we use job-to-job flow data at the state-industry level from the Longitudinal Employer-Household Dynamics database. Since our exemption classification is by occupation rather than industry, we must look at industrial employment shares across occupations using data from the Quarterly Workforce Indicators. In 2018, 25.3\% of employment in the Finance and Insurance industry (NAICS 52) was from SOC 13 and 22.6\% of Management of Companies and Enterprises (NAICS 55) was from SOC 13. The public sector (NAICS 92 in the LEHD and 99 in QWI) had $20 \%$ of total employment in SOC 33 . We therefore code these three NAICS codes as exempt.

We estimate the effect of job-to-job flow rates in affected versus exempt industries when states enact employer credit check bans by estimating the regression

$$
J 2 J_{s, n, t}=\alpha_{s, n}+\gamma_{s, t}+\mu_{n, t}+\beta \text { Ban }_{s, t} * \text { Affected }_{s, n}+\varepsilon_{s, n, t}
$$

where $s$ refers to a state, $n$ refers to an industry, and $t$ to a date. The variable J2J measures total hires from employment as a fraction of the stock of all jobs in each state-industry at that date, which we then transform logarithmically. ${ }^{23}$

Column (4) of Table 8 presents our estimate of $\beta=0.021$, which is statistically significant at the 1 percent level. Job-to-job hiring rises in industries affected by employer credit check bans, relative to exempt industries in the same state. This is consistent with employers using other signals as substitutes for credit checks, one of which is a job applicant's current employment status.

\section{Heterogeneous Effects by Occupational Task Composition}

23 These data are publicly available from the US Census Bureau as part of the Longitudinal Employer-Household Dynamics database. A Unix script for downloading the raw data in CSV format is available at http://andyecon.weebly.com/lehd.html. Industry is only available at the two-digit level, which leads us to code finance and public administration as exempt. 
While our estimates show that vacancies decline in occupations affected by employer credit check bans, and the pattern of heterogeneity is consistent with a signaling theory of credit reports' value to employers, we do not know precisely what information in the credit report is useful to employers. One possibility is that an unobservable component of cognitive ability allows a person to both perform complicated tasks and to better plan and budget their personal expenses, so good credit correlates with productivity on the job. Alternatively, people with good credit may just be more responsible in all dimensions, which signals that they will be punctual and professional employees, even if their actual ability to perform the job is the same as that of a person with bad credit.

We cannot disentangle the precise reason that employers value credit report information, but theoretically the largest declines should occur for those jobs in which the gain from observing subprime credit is largest. This leads us to estimate the differential response of vacancies in occupations in which workers perform routine tasks, relative to those in which they do nonroutine work. We follow Jaimovich and Siu (Forthcoming) for classification of the routine and nonroutine jobs, which results in about 36 percent of our sample being vacancies posted for routine-task occupations. ${ }^{24} \mathrm{We}$ then estimate the following regression

$$
V_{i, o, t}=\alpha_{i, o}+\gamma_{i, t}+\mu_{o, t}+\beta * \text { Routine }_{o} * \operatorname{Ban}_{i, t}+\varepsilon_{i, o, t},
$$

where Routine $e_{o}$ indicates the task content of the occupation. Furthermore, all of the routine occupations are affected by bans, so the comparison is to both affected and exempt non-routine occupations in the same county.

Column (3) of Table 8 presents our estimate of $\beta=-0.117$, which is significant at the 1 percent level. The decline in vacancies among affected occupations is mainly driven by a large decline in routine vacancies: column (1) of Table 10 shows that affected non-routine vacancies fall by a statistically insignificant $2.1 \%$ post ban. This suggests that credit reports are not being used to infer a worker's unobservable ability at performing nonroutine tasks and, as shown in column (2) of Table 10, the effect is essentially identical for routine cognitive and routine manual.

The extra sensitivity of non-routine vacancies to employer credit check bans is also apparent when we proxy exposure by county-level subprime shares. To make this point, columns (3) and

\footnotetext{
${ }^{24}$ Our classification follows Jaimovich and Siu (Forthcoming) and we code the following two-digit occupations as routine: Sales and Related Occupations (41), Office and Administrative Support Occupations (43), Construction and Extraction Occupations (47), Installation, Maintenance, and Repair Occupations (49), Production Occupations (51), and Transportation and Material Moving Occupations (53). The remaining two-digit occupations are coded as nonroutine, with the exception of Farming, Fishing, and Forestry Occupations and Military Specific Occupations, which are excluded from the analysis.
} 
(4) of Table 10 report estimates of Equation (10) in which we use the fraction of subprime residents in a county to proxy for exposure to the ban. While we still estimate that counties with larger subprime shares experience larger declines in affected non-routine vacancies (coefficient of -0.09), the decline in routine vacancies is much more sensitive to the share of subprime residents (coefficient of -0.58 , significant at $1 \%$ level). Furthermore, vacancies in more exposed routine manual and routine cognitive occupations decline by similar amounts following the ban.

\section{Robustness}

Before concluding, we present additional robustness exercises. First, we show that all of our estimates are similar when using the inverse hyperbolic sine of vacancies rather than the natural $\log$. Second, we show that our estimates do not change if any given ban state is dropped, nor do they change if we drop large control states. Finally, we show that labor and credit market variables that we expect to be invariant to employer credit check bans are essentially unresponsive to the laws.

Tables 11 through 15 mirror all of our baseline tables, but with the logarithm of vacancies replaced by the inverse hyperbolic sine. This transformation is defined even for countyoccupation-quarters with zero vacancies and is approximately the same as the logarithm for county-occupation-quarters with a large number of vacancies. The sample size for these estimates is typically a million county-occupation-quarters larger than with the logarithmic transformation, so the sample is quite different. Despite the larger sample, the point estimates are very close to our baseline, so our estimates are not driven by sample selection due to the logarithmic transformation. ${ }^{25}$

Figure 4 plots our point estimates and standard errors from equation (4) in which we drop one state at a time. In each case, the point estimates are similar in magnitude and always within the $95 \%$ confidence interval of the estimate using the entire nation. We conclude that no single state is driving our baseline estimate.

Finally, we estimate difference in difference regressions using variables that we expect to be approximately invariant to employer credit check and present the results in Table 16. We first look at county-level average earnings from the Quarterly Workforce Indicators (QWI) data. As with the

\footnotetext{
${ }^{25}$ Some estimates are more significantly significant with the inverse hyperbolic sine transformation, such as the contiguous county specification of our baseline regression. In other cases, the inverse hyperbolic sine estimates have larger standard errors, which is due to additional variation in the dependent variable since many county-occupationquarters with zero vacancies are followed by a quarter with one vacancy and then another with zero.
} 
LEHD, the QWI classifies employment and earnings by industry rather than occupation, so we code industries as described above. These are earnings for ongoing, stable employment relationships, so employer credit check bans have a small and insignificant effect even for affected industries $(-0.8 \%$, S.E. of $1.1 \%)$.

Second, we look at the share of employment for new firms at the county level, which is available in the QWI dataset. More formally, we look at the share of employment by firms aged 0-1 years in a county. While people with bad credit may switch from self-employment to being an employee following the ban, we expect a small aggregate effect on firm creation and column (2) shows that the employment share of new firms falls by $0.18 \%$ (S.E. of $0.07 \%$ ) following the ban, which is economically negligible.

Finally, we use annual data on bank deposits from the FDIC and find that employer credit check bans have no effect on either average or total deposits $(0.6 \%$ and $0.2 \%$, with standard errors of $1.7 \%$ and $2.1 \%$ ). These negative placebo estimates are consistent with our interpretation that affected-occupation vacancies declined because of employer credit check bans, rather than reflecting broad changes coincident with them.

\section{Conclusion}

In 2007, Washington was the first state to restrict employers' use of credit reports in hiring. Ten more states have adopted such policies since, and federal legislation has been proposed. Policy makers have argued that these bans can break a cycle in which limited employment opportunities cause financial distress, which further reduces labor market opportunities. We show that these laws have likely reduced vacancy postings in occupations for which employer credit checks have been forbidden.

Our estimates are consistent with employers using credit reports as a screening device, as in Corbae and Glover (2018). First, vacancies decline more in counties in which a large share of residents have subprime credit, a finding consistent with credit reports being more valuable signals in markets that are more adversely selected. Second, we estimate smaller effects for occupations or job flows that have other readily observable signals of worker quality: Vacancies decline less in occupations that typically require a college education, and industries affected by employer credit check bans shift hiring away from the unemployment pool and toward poaching from other employers. 
Corbae and Glover (2018) find that employer credit check bans create wide-spread welfare losses, even while greatly increasing welfare for unemployed subprime individuals. While we cannot test their model definitively, the fact that we estimate declines in vacancies that are accompanied by aggregate welfare losses in their paper suggests that employer credit check bans may reduce labor market efficiency and welfare by eliminating a useful screening tool during the recruitment process. Targeted policies that help unemployed people with bad credit without distorting the hiring process in general are likely better than employer credit check bans.

\section{REFERENCES}

Ballance, Joshua, Robert Clifford, and Daniel Shoag. 2016. "No More Credit Score: Employer Credit Check Bans and Signal Substitution.” Federal Reserve Bank of Boston Working Paper. Bartik, Alexander W., and Scott T. Nelson. 2019. "Deleting a Signal: Evidence from PreEmployment Credit Checks.” University of Chicago, Becker Friedman Institute for Economics Working Paper No. 2019-137. doi:10.2139/ssrn.2759560.

Bertrand, Marianne, and Sendhil Mullainathan. 1999. "Is There Discretion in Wage Setting? A

Test Using Takeover Legislation." Rand Journal of Economics 30(3):535:54. URL https://www.jstor.org/stable/2556062.

Bertrand, Marianne, and Sendhil Mullainathan. 2003. "Enjoying the Quiet Life? Corporate Governance and Managerial Preferences." Journal of Political Economy, 111(3):1043-75. doi:10.1086/376950.

Bos, Marieke, Emily Breza, and Andres Liberman (2018). "The labor market effects of credit market information." The Review of Financial Studies, 31(6), pp. 2005-2037. doi:10.1093/rfs/hhy006.

Cajner, Tomaz, and David D. Ratner. 2016. “A Cautionary Note on the Help Wanted Online Data." FEDS Notes. Washington: Board of Governors of the Federal Reserve System, June 23, 2016. doi:10.17016/2380-7172.1795.

Chen, W. 2017. "Legislators consider banning credit checks on job-seekers.” Telegram and Gazette. https://www.telegram.com/news/20170129/legislators-consider-banning-creditchecks-on-job-seekers

Conference Board, The. 2017. The Conference Board Help Wanted OnLine ${ }^{\circledR}$ (HWOL) [Data file and documentation]. URL https:/www.conference-board.org/ data/helpwantedonline.cfm. Corbae, Dean, and Andrew Glover. 2018. "Employer Credit Checks: Poverty Traps Versus Matching Efficiency." Working Paper 25005, National Bureau of Economic Research. 
doi:10.3386/w25005.

Demos. 2012. "Discredited: How Employer Credit Checks Keep Qualified Workers Out of a Job."

Dobbie, Will, Paul Goldsmith-Pinkham, Neale Mahoney, and Jae Song. 2019. "Bad Credit, No Problem? Credit and Labor Market Consequences of Bad Credit Reports.” Kreisman Working Papers Series in Housing Law and Policy.

Donaldson, Jason R., Giorgia Piacentino, and Anjan Thakor. Forthcoming. "Household

Debt and Unemployment.” Journal of Finance. doi:10.2139/ssrn.3203809.

Dube, A., Lester, T.W. and Reich, M., 2010. "Minimum wage effects across state borders:

Estimates using contiguous counties.” The review of economics and statistics, 92(4), pp. 945-964.

Ellis, B. 2013. "Bill aims to stop employers from conducting credit checks.” CNN. https://money.cnn.com/2013/12/17/pf/employer-credit-checks/index.html

Esen, E., M. Schmit, and J. Victor. 2012. Background Checking: The Use of Credit Background Checks in Hiring Decisions. Society of Human Resource Managers PowerPoint presentation. URL https://www.shrm.org/hr-today/trends-and-forecasting/research-andsurveys/pages/creditbackgroundchecks.aspx.

Friedberg, Leora, Richard M. Hynes, and Nathaniel Pattison. 2018. "Who Benefits from Credit Report Bans?" URL https://pattison-nate.github.io/publication/ who-benefits-from-bans-onemployer-credit-checks/.

Hall, R.E. and Schulhofer-Wohl, S., 2018. Measuring job-finding rates and matching efficiency with heterogeneous job-seekers. American Economic Journal: Macroeconomics, 10(1), pp.132.

Herkenhoff, Kyle. 2018. "The Impact of Consumer Credit Access on Unemployment." doi:10.3386/w25187.

Herkenhoff, Kyle, Gordon Phillips, and Ethan Cohen-Cole. 2016. "How Credit Constraints Impact Job-Finding Rates, Sorting and Aggregate Output.” doi:10.3386/w22274.

Jarosch, Gregor and Laura Pilossoph. 2018. "Statistical Discrimination and Duration Dependence in the Job Finding Rate," doi:10.3386/w18334.

Jaimovich, Nir, and Henry E. Siu. Forthcoming. "Job Polarization and Jobless Recoveries." Review of Economics and Statistics.

Karahan, F., Mitman, K. and Moore, B. 2019. Individual and Market-Level Effects of UI Policies: Evidence from Missouri. FRB of New York Staff Report, (905). 
Kroft, Kory, Fabian Lange and Matthew J. Notowidigdo. 2013. "Duration Dependence and Labor Market Conditions: Evidence from a Field Experiment" Quarterly Journal of Economics, 128(3):1123-67. doi:10.1093/qje/qjt015.

Maurer, R. 2020. "House approves ban on most employment credit checks.” SHRM.

https://www.shrm.org/resourcesandtools/hr-topics/talent-acquisition/pages/house-approvesban-most-employment-credit-checks.aspx

Meer, Jonathan, and Jeremy West. 2016. "Effects of the Minimum Wage on Employment Dynamics." Journal of Human Resources 51(2):500-22. doi:10.3368/jhr.51.2.0414-6298R1.

Myers v. Toojay’s Management Corp., 640 F.3d 1278 (11 ${ }^{\text {th }}$ Cir. 2011).

Nekarda, Christopher J. 2009. "A Longitudinal Analysis of the Current Population Survey: Assessing the Cyclical Bias of Geographic Mobility.” http://citeseerx.ist.psu.edu/viewdoc/download?doi=10.1.1.511.8004\&rep=rep1\&type=pdf.

"Protection against discriminatory treatment." Title 11 U.S. Code, sec. 525.

Sahin, Aysegul, J. Song, G. Topa, and G. Violante. 2014. "Mismatch Unemployment." American Economic Review 104(11): 3529-64. doi:10.1257/aer.104.11.3529.

Spence, M. 1978. “Job Market Signaling.” In P. Diamond and M. Rothschild, eds., Uncertainty in Economics. Cambridge, MA: Academic Press/Elsevier, pp. 281-306. doi:10.1016/B978-0-12214850-7.50025-5. 


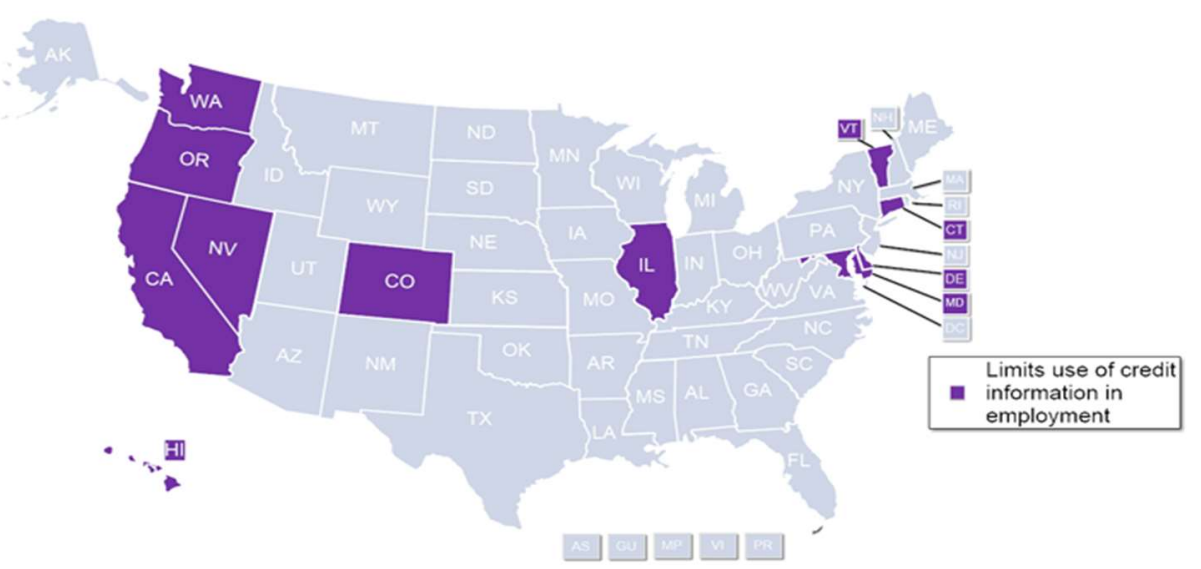

FigURE 1. CREDIT CHECK BAN LEGISLATION

Notes: State legislation recorded by the National Conference of State Legislatures.

TABLE 1: DATES WHEN BANS WENT INTO EFFECT

\begin{tabular}{|c|c|c|c|c|}
\hline State & Date of Effective Law Change & $\begin{array}{l}\text { Exempt Occupations } \\
\text { (SOC) }\end{array}$ & Neighboring States & $\begin{array}{lr}\text { Notes: } & \text { Table } \\
\text { displays } & \text { the }\end{array}$ \\
\hline $\mathrm{CA}$ & $1 / 1 / 2012$ & $13,23,33$ & $\mathrm{NV}, \mathrm{AZ}, \mathrm{OR}$ & states that have \\
\hline $\mathrm{CO}$ & $7 / 1 / 2013$ & $13,23,33$ & UT, WY, NE, KS, OK, NM & enacted \\
\hline $\mathrm{CT}$ & $10 / 1 / 2011$ & $13,23,33$ & MA, NY, RI & employer credit \\
\hline $\mathrm{DE}^{*}$ & $5 / 8 / 2014$ & Non-public Employers & $\mathrm{MD}, \mathrm{NJ}, \mathrm{PA}$ & check bans, the \\
\hline $\mathrm{HI}$ & $7 / 1 / 2009$ & $11,13,23,33$ & $\begin{array}{l}\mathrm{MID}, \mathrm{N}, \mathrm{PA} \\
\text { none }\end{array}$ & date when the \\
\hline IL & $1 / 1 / 2011$ & $13,23,33$ & IN, KY, MO, IA, WI & ban went into \\
\hline MD & $10 / 1 / 2011$ & $13,23,33$ & DE, PA, VA, WV & $\begin{array}{l}\text { effect, the two- } \\
\text { digit SOC }\end{array}$ \\
\hline NV & $10 / 1 / 2013$ & $11,13,23,33$ & $\mathrm{AZ}, \mathrm{CA}, \mathrm{ID}, \mathrm{OR}, \mathrm{UT}$ & codes that we \\
\hline OR & $3 / 29 / 2010$ & $13,23,33$ & CA,ID, NV,WA & code as exempt \\
\hline VT & $7 / 1 / 2012$ & $13,23,33$ & $\mathrm{MA}, \mathrm{NH}, \mathrm{NY}$ & occupations, \\
\hline WA & $7 / 22 / 2007$ & $13,23,33$ & $\mathrm{ID}, \mathrm{OR}$ & and the \\
\hline
\end{tabular}


TABLE 2: DISTRIBUTION OF LABOR MARKET VARIABLES AND BAN FLAG - COUNTY LEVEL

\begin{tabular}{|c|c|c|c|c|c|c|}
\hline \multirow[b]{3}{*}{ Year } & \multicolumn{6}{|c|}{ a) Credit check Ban and Unemployment Rate } \\
\hline & \multicolumn{3}{|c|}{ Law Flag } & \multicolumn{3}{|c|}{ Unemployment Rate } \\
\hline & Obs. & $\begin{array}{c}\text { Counties } \\
\text { with } \\
\text { Law in } \\
\text { Effect }\end{array}$ & $\begin{array}{l}\text { States } \\
\text { with } \\
\text { Law in } \\
\text { Effect }\end{array}$ & Obs. & Mean & Std. Dev. \\
\hline 2005 & 3,141 & 0 & 0 & 12,546 & 5.46 & 2.00 \\
\hline 2006 & 3,141 & 0 & 0 & 12,546 & 4.97 & 1.88 \\
\hline 2007 & 3,141 & 39 & 1 & 12,560 & 4.89 & 1.87 \\
\hline 2008 & 3,141 & 39 & 1 & 12,560 & 5.83 & 2.25 \\
\hline 2009 & 3,141 & 44 & 2 & 12,560 & 9.07 & 3.35 \\
\hline 2010 & 3,140 & 80 & 3 & 12,556 & 9.38 & 3.31 \\
\hline 2011 & 3,138 & 214 & 6 & 12,548 & 8.73 & 3.13 \\
\hline 2012 & 3,138 & 286 & 8 & 12,548 & 7.86 & 2.89 \\
\hline 2013 & 3,138 & 367 & 10 & 12,548 & 7.38 & 2.80 \\
\hline 2014 & 3,137 & 370 & 11 & 12,547 & 6.25 & 2.47 \\
\hline 2015 & 3,137 & 370 & 11 & 12,544 & 5.53 & 2.14 \\
\hline 2016 & 3,137 & 370 & 11 & 12,544 & 5.25 & 1.99 \\
\hline $\begin{array}{c}\text { All } \\
\text { Years }\end{array}$ & -- & -- & -- & 150,607 & 6.72 & 3.03 \\
\hline
\end{tabular}

b) Log Specification

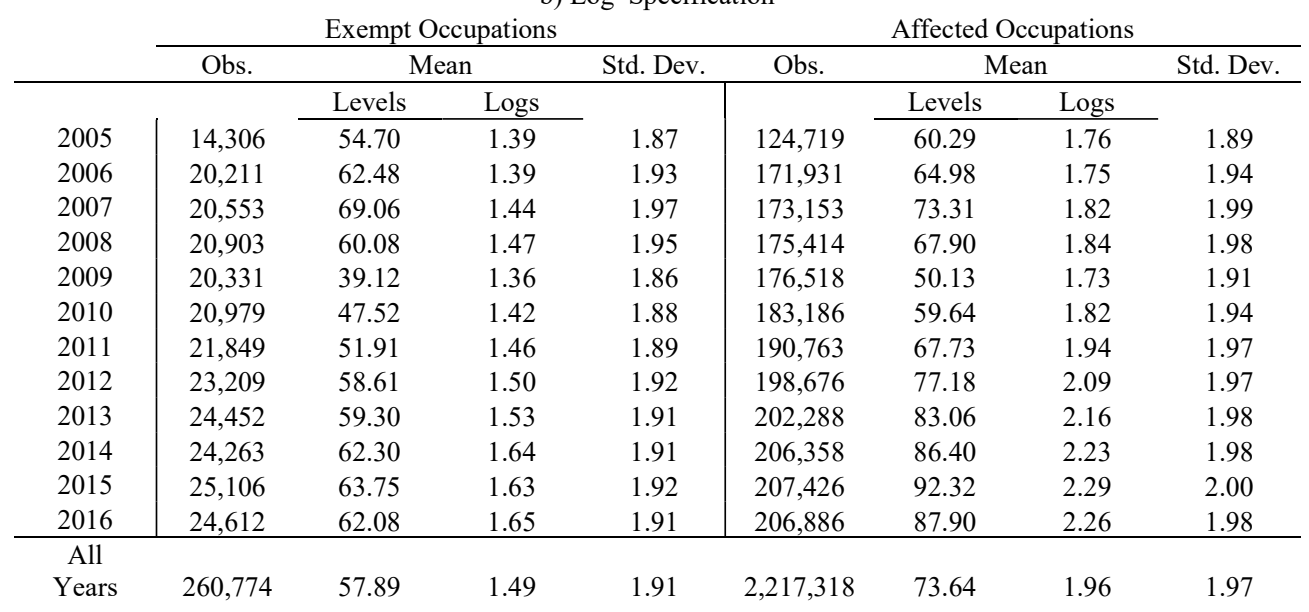

c) Inverse Hyperbolic Sine Specification

Exempt Occupations

\begin{tabular}{|c|c|c|c|c|c|c|c|c|}
\hline & \multicolumn{4}{|c|}{ Exempt Occupations } & \multicolumn{4}{|c|}{ Affected Occupations } \\
\hline & \multirow[t]{2}{*}{ Obs. } & \multicolumn{2}{|c|}{ Mean } & \multirow[t]{2}{*}{ Std. Dev. } & \multirow[t]{2}{*}{ Obs. } & \multicolumn{2}{|c|}{ Mean } & \multirow[t]{2}{*}{ Std. Dev. } \\
\hline & & Levels & Logs & & & Levels & Logs & \\
\hline 2005 & 28,290 & 27.65 & 1.12 & 1.66 & 188,094 & 39.96 & 1.12 & 1.66 \\
\hline 2006 & 37,720 & 27.65 & 1.20 & 1.71 & 250,792 & 44.53 & 1.20 & 1.71 \\
\hline 2007 & 37,720 & 37.61 & 1.25 & 1.76 & 250,792 & 50.60 & 1.25 & 1.76 \\
\hline 2008 & 37,720 & 33.28 & 1.28 & 1.77 & 250,792 & 47.47 & 1.28 & 1.77 \\
\hline 2009 & 37,720 & 21.07 & 1.19 & 1.66 & 250,792 & 35.26 & 1.19 & 1.66 \\
\hline 2010 & 37,708 & 26.42 & 1.26 & 1.71 & 250,712 & 43.54 & 1.26 & 1.71 \\
\hline 2011 & 37,684 & 30.06 & 1.33 & 1.74 & 250,552 & 51.50 & 1.33 & 1.74 \\
\hline 2012 & 37,684 & 36.05 & 1.44 & 1.80 & 250,552 & 61.12 & 1.44 & 1.80 \\
\hline 2013 & 37,684 & 38.43 & 1.53 & 1.82 & 250,552 & 66.97 & 1.53 & 1.82 \\
\hline 2014 & 37,681 & 40.06 & 1.58 & 1.85 & 250,532 & 71.07 & 1.58 & 1.85 \\
\hline 2015 & 37,672 & 42.43 & 1.63 & 1.86 & 250,472 & 76.33 & 1.63 & 1.86 \\
\hline 2016 & 37,672 & 40.49 & 1.61 & 1.85 & 250,472 & 72.48 & 1.61 & 1.85 \\
\hline All & & & & & & & & \\
\hline Years & 442,955 & 34.05 & 1.37 & 1.78 & $2,945,106$ & 55.38 & 1.37 & 1.78 \\
\hline
\end{tabular}

Note: Table displays summary statistics of variables used in the analysis. Panel a) summarizes the "Law Flag" and county-level unemployment rate. "Law Flag" columns depict the number of states (and counties) that have passed employer credit check bans in each year. In panel b), "Affected Occupations" and "Exempt

Occupations" display cross-sectional means and standard deviations of vacancies for each year in our log specification. Panel c) presents the same moments for the sample in the inverse hyperbolic sine specification. 
TABLE 3: DISTRIBUTION OF VACANCIES IN ADJACENT COUNTY SAMPLE - COUNTY LEVEL

a) $\log$ (Vacancies)

\begin{tabular}{ccccccc}
\hline & \multicolumn{3}{c}{ Exempt Occupations } & \multicolumn{3}{c}{ Affected Occupations } \\
\cline { 2 - 7 } Year & Obs. & Mean & Std. Dev. & Obs. & Mean & Std. Dev. \\
\hline 2005 & 11,527 & 1.39 & 1.87 & 100,710 & 1.76 & 1.86 \\
2006 & 16,338 & 1.39 & 1.93 & 138,209 & 1.74 & 1.92 \\
2007 & 16,514 & 1.45 & 1.98 & 138,357 & 1.81 & 1.97 \\
2008 & 16,730 & 1.49 & 1.96 & 140,060 & 1.83 & 1.97 \\
2009 & 16,180 & 1.40 & 1.87 & 140,391 & 1.72 & 1.90 \\
2010 & 16,989 & 1.46 & 1.87 & 146,246 & 1.83 & 1.93 \\
2011 & 17,670 & 1.50 & 1.88 & 151,744 & 1.94 & 1.96 \\
2012 & 18,837 & 1.52 & 1.92 & 157,719 & 2.08 & 1.95 \\
2013 & 19,789 & 1.53 & 1.90 & 161,034 & 2.14 & 1.97 \\
2014 & 19,552 & 1.63 & 1.90 & 164,459 & 2.20 & 1.96 \\
2015 & 20,325 & 1.62 & 1.91 & 165,108 & 2.28 & 1.98 \\
2016 & 19,902 & 1.65 & 1.90 & 164,888 & 2.25 & 1.96 \\
\hline All Years & 210,353 & 1.51 & 1.91 & $1,768,925$ & 1.98 & 1.96
\end{tabular}

b) Inverse Hyperbolic Sine Transformation of Vacancies

\begin{tabular}{ccccccc}
\hline & \multicolumn{3}{c}{ Exempt Occupations } & \multicolumn{3}{c}{ Affected Occupations } \\
\cline { 2 - 7 } Year & Obs. & Mean & Std. Dev. & Obs. & Mean & Std. Dev. \\
\hline 2005 & 22,590 & 1.13 & 1.66 & 149,772 & 1.72 & 1.87 \\
2006 & 30,120 & 1.21 & 1.72 & 199,696 & 1.76 & 1.90 \\
2007 & 30,120 & 1.26 & 1.77 & 199,696 & 1.81 & 1.95 \\
2008 & 30,120 & 1.29 & 1.78 & 199,696 & 1.85 & 1.96 \\
2009 & 30,120 & 1.21 & 1.68 & 199,696 & 1.78 & 1.88 \\
2010 & 30,120 & 1.30 & 1.73 & 199,696 & 1.93 & 1.93 \\
2011 & 30,120 & 1.36 & 1.75 & 199,696 & 2.08 & 1.98 \\
2012 & 30,120 & 1.47 & 1.80 & 199,696 & 2.26 & 2.01 \\
2013 & 30,120 & 1.55 & 1.81 & 199,696 & 2.36 & 2.03 \\
2014 & 30,120 & 1.59 & 1.84 & 199,696 & 2.45 & 2.03 \\
2015 & 30,120 & 1.65 & 1.85 & 199,696 & 2.52 & 2.06 \\
2016 & 30,120 & 1.63 & 1.85 & 199,696 & 2.49 & 2.04 \\
\hline All Years & 353,910 & 1.39 & 1.78 & $2,346,428$ & 2.09 & 1.99
\end{tabular}

Notes: Table displays summary statistics for vacancies in the adjacent-county sample. Panel a) presents the crosssectional means and standard deviations of log-vacancies for each year in this sample whereas panel b) shows that same moments for inverse hyperbolic sine transformation of the vacancy data. 


\begin{tabular}{cccccccc}
\hline & & & \multicolumn{3}{c}{ Fraction Subprime } & & \\
Year & Obs. & Mean & 25th pct & Median & 75th pct & 95th pct & Std. dev. \\
\hline 2005 & 12,560 & 0.29 & 0.20 & 0.27 & 0.36 & 0.5 & 0.12 \\
2006 & 12,560 & 0.29 & 0.20 & 0.27 & 0.36 & 0.5 & 0.12 \\
2007 & 12,559 & 0.28 & 0.20 & 0.27 & 0.36 & 0.49 & 0.12 \\
2008 & 12,556 & 0.28 & 0.20 & 0.27 & 0.35 & 0.48 & 0.11 \\
2009 & 12,556 & 0.28 & 0.20 & 0.27 & 0.35 & 0.47 & 0.11 \\
2010 & 12,548 & 0.26 & 0.20 & 0.26 & 0.34 & 0.46 & 0.11 \\
2011 & 12,548 & 0.27 & 0.19 & 0.25 & 0.33 & 0.46 & 0.11 \\
2012 & 12,548 & 0.26 & 0.19 & 0.25 & 0.33 & 0.46 & 0.11 \\
2013 & 12,546 & 0.26 & 0.18 & 0.24 & 0.32 & 0.45 & 0.11 \\
2014 & 12,544 & 0.25 & 0.17 & 0.24 & 0.32 & 0.44 & 0.11 \\
2015 & 12,544 & 0.24 & 0.17 & 0.23 & 0.31 & 0.44 & 0.11 \\
2016 & 12,544 & 0.24 & 0.17 & 0.23 & 0.31 & 0.43 & 0.11 \\
\hline All years & 150,613 & 0.27 & 0.19 & 0.26 & 0.34 & 0.47 & 0.11
\end{tabular}

Notes: Table displays moments of cross-sectional distribution of subprime shares across counties in each year. Fraction of subprime borrowers in a county is determined by counting the number of borrowers residing in each county with an Equifax risk score below 620 .

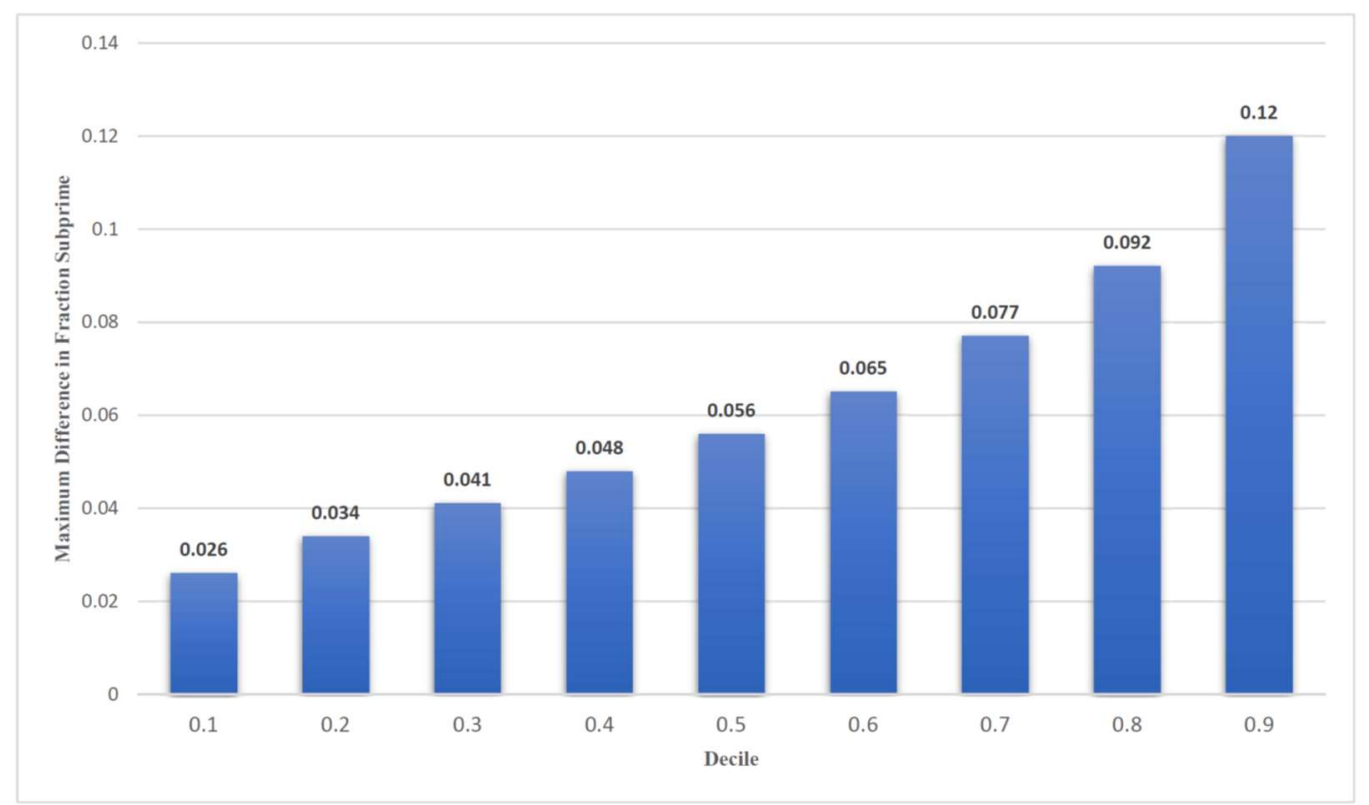

FIGURE 2. WITHIN-COUNTY VARIATION IN FRACTION SUBPRIME

Notes: This figure plots the distribution of a measure of within-county variation in the fraction of subprime borrowers over time. The measure of variation we use is the maximum absolute quarter-on-quarter change in the subprime share for a given county, relative to the cross-sectional average value in 2005 . 
TABLE 5: BASELINE REGRESSIONS - EXEMPTION STATUS

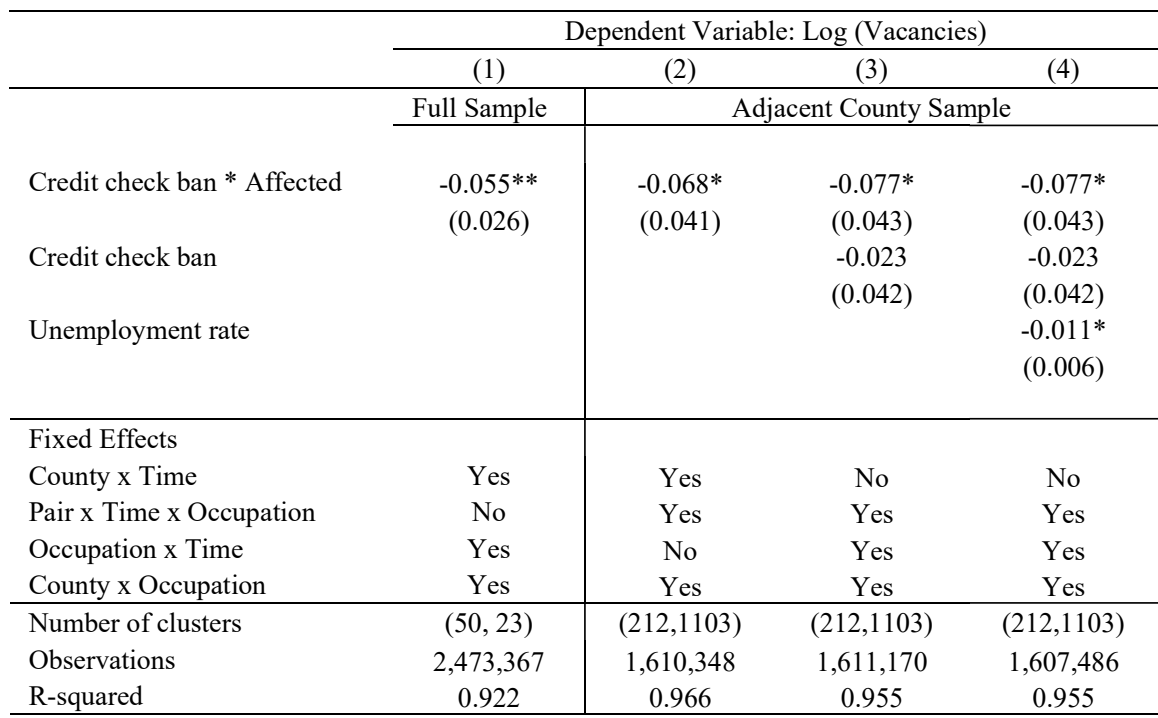

Standard errors clustered by state and occupation in (1) and by border and state-occupation in (2)-

(4).

$* * * \mathrm{p}<0.01, * * \mathrm{p}<0.05, * \mathrm{p}<0.1$

Notes: This table reports OLS regressions for the dependent variable $\log$ (vacancies) for each occupation $o$, in county $c$ (or county pair $p$ ) at time $t$ (quarterly). Column (1) displays the results from our full sample whereas (2) - (4) display the results for the adjacent-county sub-sample.

Regressions include all states, except for Delaware, and include Washington D.C. 
TABLE 6: DYNAMIC EFFECTS OF CREDIT CHECK BANS ON LABOR DEMAND

\begin{tabular}{|c|c|c|c|c|c|}
\hline & \multicolumn{4}{|c|}{ Dependent Variable: Log (Vacancies) } & \multirow{2}{*}{$\frac{\log (\mathrm{J} 2 \mathrm{~J})}{(5)}$} \\
\hline & (1) & (2) & (3) & (4) & \\
\hline & $\begin{array}{c}\text { Exemption } \\
\text { Status }\end{array}$ & $\begin{array}{c}\text { Subprime } \\
\text { Fraction }\end{array}$ & Less Skilled & Routine & $\begin{array}{c}\text { Exemption } \\
\text { Status }\end{array}$ \\
\hline Interaction with credit check ban, $t-4$ & $\begin{array}{l}0.042 * \\
(0.021)\end{array}$ & $\begin{array}{l}0.180 * \\
(0.104)\end{array}$ & $\begin{array}{c}0.048 \\
(0.064)\end{array}$ & $\begin{array}{l}-0.000 \\
(0.044)\end{array}$ & $\begin{array}{c}0.002 \\
(0.021)\end{array}$ \\
\hline Interaction with credit check ban, $t-3$ & $\begin{array}{l}-0.001 \\
(0.020)\end{array}$ & $\begin{array}{c}0.022 \\
(0.085)\end{array}$ & $\begin{array}{c}0.032 \\
(0.061)\end{array}$ & $\begin{array}{l}-0.011 \\
(0.035)\end{array}$ & $\begin{array}{l}-0.008 \\
(0.022)\end{array}$ \\
\hline Interaction with credit check ban, $t-2$ & $\begin{array}{l}-0.027 \\
(0.025)\end{array}$ & $\begin{array}{l}-0.128 \\
(0.111)\end{array}$ & $\begin{array}{l}-0.025 \\
(0.037)\end{array}$ & $\begin{array}{l}-0.062 * \\
(0.031)\end{array}$ & $\begin{array}{c}0.003 \\
(0.015)\end{array}$ \\
\hline Interaction with credit check ban, $t-1$ & $\begin{array}{l}-0.046 \\
(0.034)\end{array}$ & $\begin{array}{l}-0.195 \\
(0.147)\end{array}$ & $\begin{array}{l}-0.001 \\
(0.056)\end{array}$ & $\begin{array}{l}-0.067 * \\
(0.033)\end{array}$ & $\begin{array}{c}0.024 \\
(0.018)\end{array}$ \\
\hline Interaction with credit check ban, $t$ & $\begin{array}{l}-0.002 \\
(0.036)\end{array}$ & $\begin{array}{c}0.032 \\
(0.149)\end{array}$ & $\begin{array}{c}0.001 \\
(0.064)\end{array}$ & $\begin{array}{l}-0.044 \\
(0.039)\end{array}$ & $\begin{array}{c}0.017 \\
(0.015)\end{array}$ \\
\hline Interaction with credit check ban, $t+1$ & $\begin{array}{l}-0.052 * \\
(0.029)\end{array}$ & $\begin{array}{c}-0.253 * * \\
(0.110)\end{array}$ & $\begin{array}{l}-0.097 \\
(0.067)\end{array}$ & $\begin{array}{l}-0.084 * \\
(0.048)\end{array}$ & $\begin{array}{l}0.031 * \\
(0.016)\end{array}$ \\
\hline Interaction with credit check ban, $t+2$ & $\begin{array}{c}-0.074 * * \\
(0.028)\end{array}$ & $\begin{array}{c}-0.316 * * * \\
(0.111)\end{array}$ & $\begin{array}{c}-0.151 * * \\
(0.062)\end{array}$ & $\begin{array}{c}-0.128 * * \\
(0.046)\end{array}$ & $\begin{array}{l}0.034 * \\
(0.017)\end{array}$ \\
\hline Interaction with credit check ban, $t+3$ & $\begin{array}{c}-0.103 * * * \\
(0.036)\end{array}$ & $\begin{array}{c}-0.434 * * * \\
(0.141)\end{array}$ & $\begin{array}{l}-0.079 \\
(0.068)\end{array}$ & $\begin{array}{l}-0.090 * \\
(0.052)\end{array}$ & $\begin{array}{c}0.029 * * * \\
(0.009)\end{array}$ \\
\hline Interaction with credit check ban, $t+4$ & $\begin{array}{l}-0.057 \\
(0.036)\end{array}$ & $\begin{array}{l}-0.209 \\
(0.135)\end{array}$ & $\begin{array}{l}-0.092 \\
(0.085)\end{array}$ & $\begin{array}{c}-0.095 * * \\
(0.045)\end{array}$ & $\begin{array}{c}0.015 \\
(0.016)\end{array}$ \\
\hline Interaction with credit check ban, $t>4$ & $\begin{array}{l}-0.056^{*} \\
(0.030)\end{array}$ & $\begin{array}{c}-0.243 * * \\
(0.111)\end{array}$ & $\begin{array}{l}-0.164 \\
(0.087)\end{array}$ & $\begin{array}{c}-0.137 * * \\
(0.049)\end{array}$ & $\begin{array}{c}0.021 * * * \\
(0.007)\end{array}$ \\
\hline $\begin{array}{l}\text { Fixed Effects } \\
\text { County x Time } \\
\text { County x Occupation } \\
\text { Occupation x Time } \\
\text { County x Education } \\
\text { Education x Time } \\
\text { State x Time } \\
\text { State x Industry } \\
\text { Industry x Time } \\
\end{array}$ & $\begin{array}{l}\text { Yes } \\
\text { Yes } \\
\text { Yes } \\
\text { No } \\
\text { No } \\
\text { No } \\
\text { No } \\
\text { No } \\
\end{array}$ & $\begin{array}{l}\text { Yes } \\
\text { Yes } \\
\text { Yes } \\
\text { No } \\
\text { No } \\
\text { No } \\
\text { No } \\
\text { No } \\
\end{array}$ & $\begin{array}{l}\text { Yes } \\
\text { No } \\
\text { No } \\
\text { Yes } \\
\text { Yes } \\
\text { No } \\
\text { No } \\
\text { Yes } \\
\end{array}$ & $\begin{array}{l}\text { Yes } \\
\text { Yes } \\
\text { Yes } \\
\text { No } \\
\text { No } \\
\text { No } \\
\text { No } \\
\text { No } \\
\end{array}$ & $\begin{array}{l}\text { No } \\
\text { No } \\
\text { No } \\
\text { No } \\
\text { No } \\
\text { Yes } \\
\text { Yes } \\
\text { Yes } \\
\end{array}$ \\
\hline $\begin{array}{l}\text { Number of clusters } \\
\text { Observations } \\
\text { R-squared }\end{array}$ & $\begin{array}{c}(50,23) \\
2,473,367 \\
0.922 \\
\end{array}$ & $\begin{array}{c}(50,23) \\
2,473,367 \\
0.922 \\
\end{array}$ & $\begin{array}{c}(50,8) \\
976,287 \\
0.943 \\
\end{array}$ & $\begin{array}{c}(50,23) \\
2,473,367 \\
0.922 \\
\end{array}$ & $\begin{array}{c}(50,20) \\
58,208 \\
0.970 \\
\end{array}$ \\
\hline
\end{tabular}

Standard errors clustered by state and occupation in (1)-(4) and by state and industry in (5).

$* * * \mathrm{p}<0.01, * * \mathrm{p}<0.05, * \mathrm{p}<0.1$

Notes: This table reports OLS regressions for two dependent variables; $\log$ (vacancies) for each county $\mathrm{i}$, at date (quarter) $\mathrm{t}$, for occupation o, in columns (1) through (4), and job-to-job flows for a state $\mathrm{s}$, in industry $\mathrm{n}$ at date (quarter) t, in column (5). Column (1) reports the result for the dynamic version of our baseline specification. Analogously, columns (2) - (5) display the dynamic versions of equation (7), (8), (10) and (9), respectively.

Regressions include all states, except for Delaware, and include Washington D.C. 


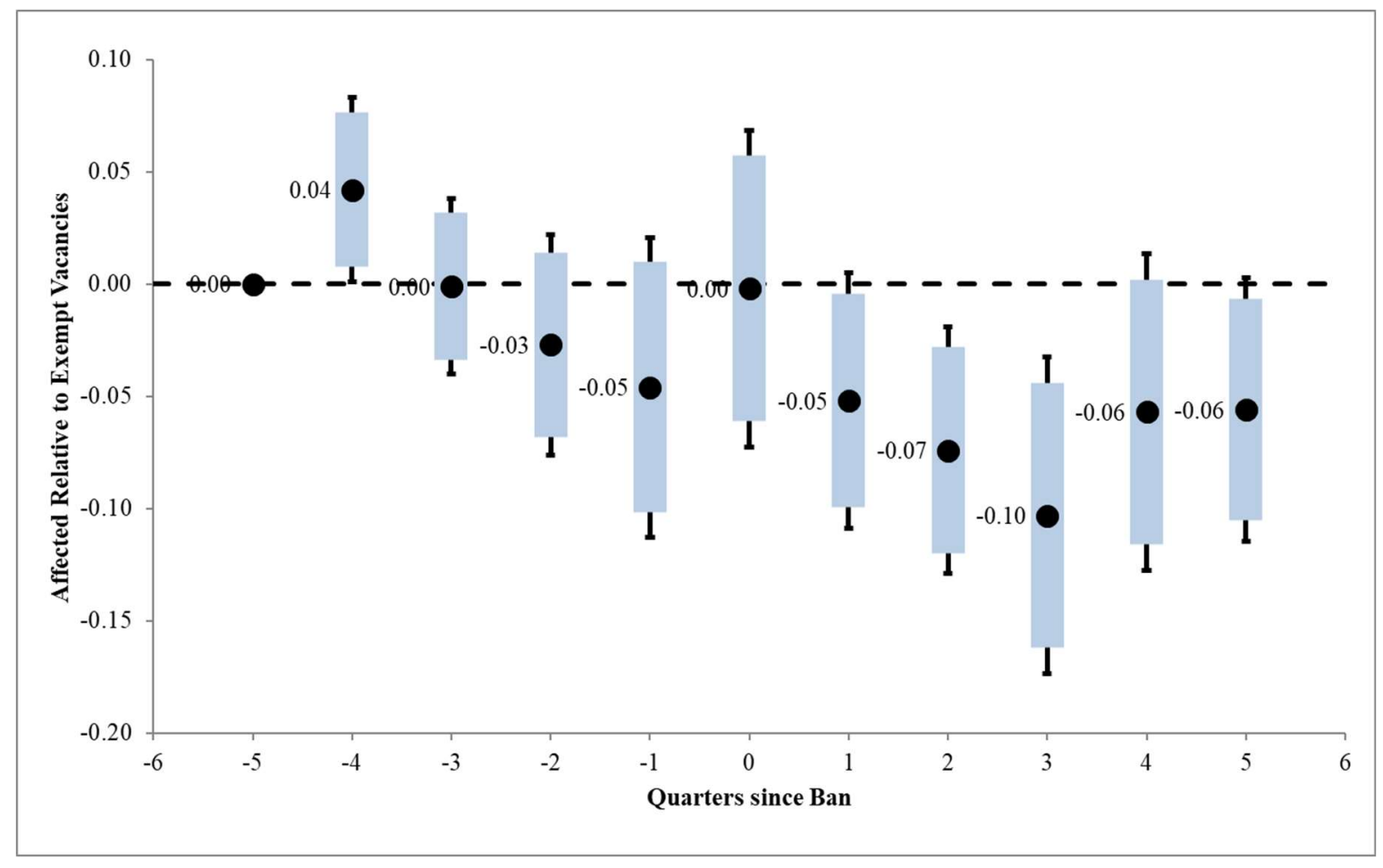

FiguRE 3: DyNAMICS OF VACANCIES FOR AFFECTED RELATIVE TO EXEMPT OCCUPATIONS

Notes: Figure 3 displays estimates of $\beta_{j}$ from regression equation (6) in the text. Solid circles correspond to point estimates, while solid box error bars correspond to $90 \%$ confidence intervals and capped lines correspond to $95 \%$ confidence intervals. Quarters -5 and 5 correspond to average in periods more than one year before and after the ban and all differences are relative to periods more than one year before the ban $(-5$ is zero by construction). Regressions include all states, except for Delaware, and include Washington D.C. 
TABLE 7: CHANGES IN OTHER LABOR MARKET OUTCOMES POST BAN

\begin{tabular}{lc|c|c|c}
\hline & $\begin{array}{c}\log \text { (Unemployment } \\
\text { Rate) - LAUS }\end{array}$ & $\begin{array}{c}\text { Log (Separation } \\
\text { Rate) - CPS }\end{array}$ & $\begin{array}{c}\text { Log (Job Finding } \\
\text { Rate) - CPS }\end{array}$ & $\begin{array}{c}\text { Log (Job finding } \\
\text { Rate) - UI Claims }\end{array}$ \\
\cline { 2 - 5 } & $(1)$ & $(2)$ & $(3)$ & $(4)$ \\
Credit check ban & 0.012 & 0.027 & -0.027 & $-0.150^{*}$ \\
& $(0.038)$ & $(0.030)$ & $(0.022)$ & $(0.080)$ \\
\hline Fixed Effects & & & & \\
County / State & Yes & Yes & Yes & Yes \\
Time & Yes & Yes & Yes & Yes \\
\hline Number of clusters & 50 & 51 & 51 & 43 \\
Observations & 150,463 & 2,346 & 2,346 & 120,356 \\
R-squared & 0.858 & 0.826 & 0.659 & 0.105 \\
\hline
\end{tabular}

$* * * \mathrm{p}<0.01, * * \mathrm{p}<0.05, * \mathrm{p}<0.1$

Notes: This table reports OLS regressions for various labor market measures at a quarterly frequency. Column (1) reports the regression results for dependent variable, unemployment rate at the county level. Columns (2) and (3) report the regression coefficients with state-level $(\log )$ separation and finding rates as the dependent variable. Column (4) reports regression results for the job-finding rate computed from county-level unemployment insurance claims used in Hagedorn et al. (2019). 
TABLE 8: HETEROGENEITY ANALYSIS - INSPECTING THE MECHANISM

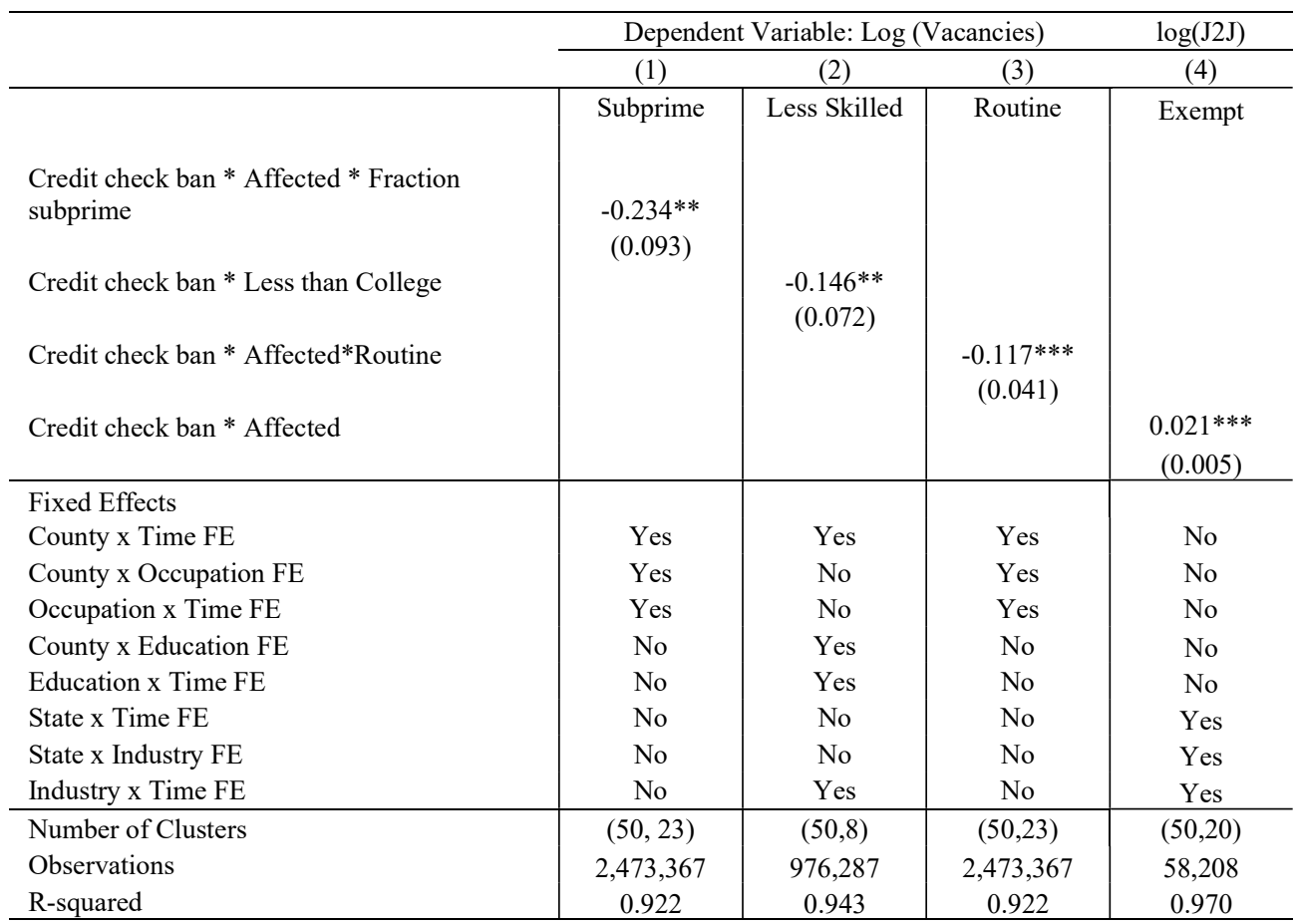

Standard errors clustered two-way.

$* * * \mathrm{p}<0.01, * * \mathrm{p}<0.05, * \mathrm{p}<0.1$

Notes: This table reports OLS regressions for two dependent variables; $\log$ (vacancies) for each county $i$, at date (quarter) $t$, for occupation o, in columns (1) through (3), and job-to-job flows for a state $\mathrm{s}$, in industry $n$ at date (quarter) $t$, in column (4). Column (1) reports the result for the baseline specification exploring the role of heterogeneity by county-level subprime rates expressed in equation (7) in the text. Analogously, columns (2) (4) display the estimates of the regression coefficients from specifications (8), (10) and (9), respectively. We have two-way clustered standard errors for each regression reported in the table. First set of clusters always refer to the number of states and the second group indicates the appropriate number of occupations, education groups, or industries. 
TABLE 9: ALTERNATIVE MEASURES OF COUNTY EXPOSURE TO BAN

\begin{tabular}{|c|c|c|c|}
\hline & \multicolumn{3}{|c|}{ Dependent Variable: Log (Vacancies) } \\
\hline & (1) & (2) & (3) \\
\hline $\begin{array}{l}\text { Credit check ban * Affected * Fraction subprime } \\
\text { Credit check ban * Affected * Std. Dev. of Risk } \\
\text { Scores } \\
\text { Credit check ban * Affected * 90/10 Ratio of Risk } \\
\text { Scores }\end{array}$ & $\begin{array}{c}-0.024 * * \\
(0.010)\end{array}$ & $\begin{array}{c}-0.006^{* *} \\
(0.003)\end{array}$ & $\begin{array}{c}-0.008 * * \\
(0.003)\end{array}$ \\
\hline $\begin{array}{l}\text { Fixed Effects } \\
\text { County x Time } \\
\text { Occupation x Time } \\
\text { County x Occupation }\end{array}$ & $\begin{array}{l}\text { Yes } \\
\text { Yes } \\
\text { Yes }\end{array}$ & $\begin{array}{l}\text { Yes } \\
\text { Yes } \\
\text { Yes }\end{array}$ & $\begin{array}{l}\text { Yes } \\
\text { Yes } \\
\text { Yes } \\
\end{array}$ \\
\hline $\begin{array}{l}\text { Number of Clusters } \\
\text { Observations } \\
\text { R-squared }\end{array}$ & $\begin{array}{c}(50,23) \\
2,473,367 \\
0.922\end{array}$ & $\begin{array}{c}(50,23) \\
2,472,816 \\
0.922 \\
\end{array}$ & $\begin{array}{c}(50,23) \\
2,473,153 \\
0.922\end{array}$ \\
\hline
\end{tabular}

Standard errors clustered by state and occupation.

$* * * \mathrm{p}<0.01, * * \mathrm{p}<0.05, * \mathrm{p}<0.1$

Notes: This table reports OLS regressions for our specification in equation 7 for $\log$ (vacancies), replacing the fraction of subprime residents with different moments of the county-level distribution of risk scores. Each regression coefficient is normalized by the cross-sectional standard deviation of that variable to maintain comparability. Column (1) corresponds to the baseline measure, which is the fraction of residents with a subprime credit score. The second column uses the county-level standard deviation of risk scores as the relevant metric and the third uses the 90/10 ratio of risk scores.

Regressions include all states, except for Delaware, and include Washington D.C. 
TABLE 10: OCCUPATIONAL TASK COMPOSITION AND EXPOSURE TO THE BAN

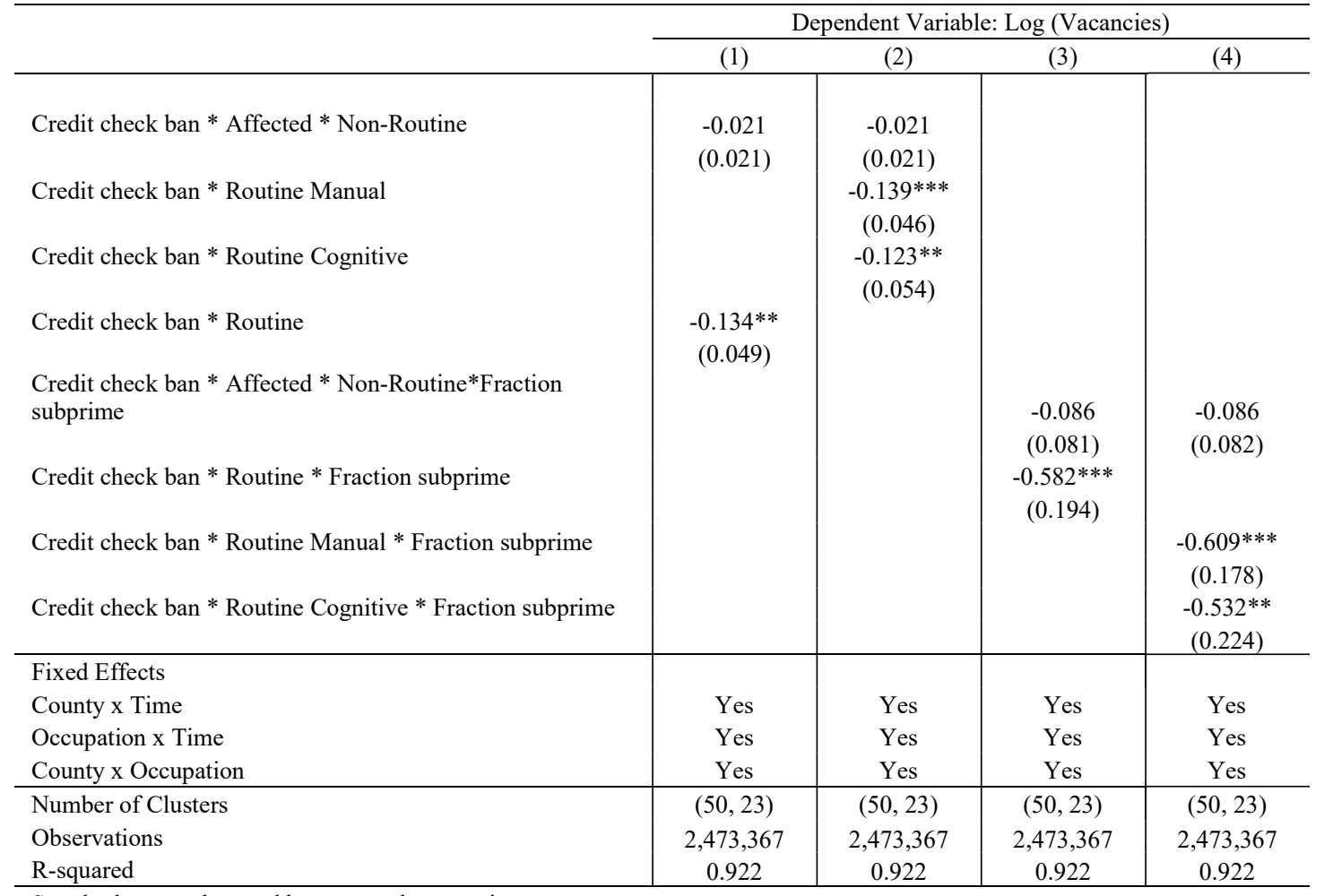

Standard errors clustered by state and occupation.

$* * * \mathrm{p}<0.01, * * \mathrm{p}<0.05, * \mathrm{p}<0.1$

Notes: This table reports OLS regressions for $\log$ (vacancies) for each county $i$, at date (quarter) $t$, for occupation o, on various different interactions of the exposure to the ban by occupational and county level heterogeneity. We have two-way clustered standard errors for each regression reported in the table. First set of clusters always refer to the number of states and the second group indicates the appropriate number of occupations, education groups, or industries. For a detailed description of the mapping between two-digit SOC codes and the routine task content of an occupation, please see section 5.D in the text. Regressions include all states, except for Delaware, and include Washington D.C. 
TABLE 11: BASELINE REGRESSIONS EXEMPTION STATUS - The role of zero Vacancies

\begin{tabular}{lc|ccc}
\hline & \multicolumn{5}{c}{ Dependent Variable: Inverse Hyperbolic Sine Transformation of } \\
\cline { 2 - 5 } & \multicolumn{5}{c}{$(1)$} & $(2)$ & $(3)$ & $(4)$ \\
& Full Sample & \multicolumn{3}{c}{ Adjacent County Sample } \\
\cline { 2 - 5 } Credit check ban * Affected & & & & \\
& $-0.052^{*}$ & $-0.078^{* *}$ & $-0.077^{* *}$ & $-0.077^{* *}$ \\
Credit check ban & $(0.029)$ & $(0.036)$ & $(0.035)$ & $(0.034)$ \\
& & & -0.030 & -0.030 \\
Unemployment rate & & & $(0.031)$ & $(0.030)$ \\
& & & & -0.007 \\
& & & & $(0.006)$ \\
Fixed Effects & & & & \\
County x Time & Yes & Yes & No & No \\
Pair x Time x Occupation & No & Yes & Yes & Yes \\
Occupation x Time & Yes & Yes & Yes & Yes \\
County x Occupation & $(50,23)$ & $(212,1103)$ & $(212,1103)$ & $(212,1103)$ \\
\hline Number of clusters & $3,388,061$ & $2,700,338$ & $2,700,338$ & $2,693,484$ \\
Observations & 0.943 & 0.972 & 0.964 & 0.964 \\
R-squared & & &
\end{tabular}

Standard errors clustered are clustered two-way.

$* * * \mathrm{p}<0.01,{ }^{* *} \mathrm{p}<0.05,{ }^{*} \mathrm{p}<0.1$

Notes: This table reports OLS regressions for the inverse-hyperbolic sine transformation of the dependent variable vacancies for each occupation $o$, in county $c$ (or county pair $p$ ) at time $t$ (quarterly). Column (1) displays the results from our full sample whereas (2) - (4) display the results for the adjacent-county sub-sample. Standard errors are clustered by state and occupation in column (1) and by borders and state-by-occupation tuples in the adjacent-county sample. 
TABLE 12: DYNAMIC EFFECTS OF CREDIT CHECK BANS ON LABOR DEMAND THE ROLE OF ZERO VACANCIES

\begin{tabular}{|c|c|c|c|c|}
\hline & \multicolumn{4}{|c|}{$\begin{array}{c}\text { Dependent Variable: Inverse Hyperbolic Sine } \\
\text { Transformation of Vacancies }\end{array}$} \\
\hline & $(1)$ & $(2)$ & (3) & (4) \\
\hline & $\begin{array}{l}\text { Exemption } \\
\text { Status }\end{array}$ & $\begin{array}{l}\text { Subprime } \\
\text { Fraction }\end{array}$ & Less Skilled & Routine \\
\hline Interaction with credit check ban, $t-4$ & $\begin{array}{l}-0.002 \\
(0.022)\end{array}$ & $\begin{array}{l}-0.002 \\
(0.103)\end{array}$ & $\begin{array}{c}0.061 \\
(0.073)\end{array}$ & $\begin{array}{l}-0.017 \\
(0.041)\end{array}$ \\
\hline Interaction with credit check ban, $t-3$ & $\begin{array}{c}0.001 \\
(0.024)\end{array}$ & $\begin{array}{c}0.008 \\
(0.112)\end{array}$ & $\begin{array}{c}0.046 \\
(0.062)\end{array}$ & $\begin{array}{l}-0.009 \\
(0.035)\end{array}$ \\
\hline Interaction with credit check ban, $t-2$ & $\begin{array}{l}-0.017 \\
(0.021)\end{array}$ & $\begin{array}{l}-0.088 \\
(0.109)\end{array}$ & $\begin{array}{l}-0.009 \\
(0.047)\end{array}$ & $\begin{array}{l}-0.047 \\
(0.035)\end{array}$ \\
\hline Interaction with credit check ban, $t-1$ & $\begin{array}{l}-0.038 \\
(0.030)\end{array}$ & $\begin{array}{l}-0.172 \\
(0.134)\end{array}$ & $\begin{array}{c}0.013 \\
(0.061)\end{array}$ & $\begin{array}{l}-0.048 \\
(0.038)\end{array}$ \\
\hline Interaction with credit check ban, $t$ & $\begin{array}{l}-0.012 \\
(0.029)\end{array}$ & $\begin{array}{l}-0.036 \\
(0.129)\end{array}$ & $\begin{array}{l}-0.011 \\
(0.064)\end{array}$ & $\begin{array}{l}-0.038 \\
(0.037)\end{array}$ \\
\hline Interaction with credit check ban, $1+1$ & $\begin{array}{l}-0.043 \\
(0.026)\end{array}$ & $\begin{array}{l}-0.205^{*} \\
(0.104)\end{array}$ & $\begin{array}{l}-0.093 \\
(0.066)\end{array}$ & $\begin{array}{l}-0.084 * \\
(0.046)\end{array}$ \\
\hline Interaction with credit check ban, $t+2$ & $\begin{array}{c}-0.073 * * \\
(0.031)\end{array}$ & $\begin{array}{c}-0.321 * * \\
(0.129)\end{array}$ & $\begin{array}{l}-0.128 \\
(0.070)\end{array}$ & $\begin{array}{c}-0.128 * * * \\
(0.044)\end{array}$ \\
\hline Interaction with credit check ban, $t+3$ & $\begin{array}{c}-0.100 * * * \\
(0.035)\end{array}$ & $\begin{array}{c}-0.426 * * \\
(0.157)\end{array}$ & $\begin{array}{l}-0.072 \\
(0.071)\end{array}$ & $\begin{array}{c}-0.108 * * \\
(0.045)\end{array}$ \\
\hline Interaction with credit check ban, $t+4$ & $\begin{array}{l}-0.052 \\
(0.033)\end{array}$ & $\begin{array}{l}-0.204 \\
(0.130)\end{array}$ & $\begin{array}{l}-0.095 \\
(0.089)\end{array}$ & $\begin{array}{l}-0.094 * \\
(0.046)\end{array}$ \\
\hline Interaction with credit check ban, $t>4$ & $\begin{array}{l}-0.054 \\
(0.035) \\
\end{array}$ & $\begin{array}{l}-0.244 \\
(0.148) \\
\end{array}$ & $\begin{array}{l}-0.185 * \\
(0.092) \\
\end{array}$ & $\begin{array}{c}-0.133 * * \\
(0.051) \\
\end{array}$ \\
\hline $\begin{array}{l}\text { Fixed Effects } \\
\text { County x Time FE } \\
\text { County x Occupation FE } \\
\text { Occupation x Time FE } \\
\text { County x Education FE } \\
\text { Education x Time FE } \\
\text { State x Time FE } \\
\text { State x Industry FE } \\
\text { Industry x Time FE } \\
\end{array}$ & $\begin{array}{l}\text { Yes } \\
\text { Yes } \\
\text { Yes } \\
\text { No } \\
\text { No } \\
\text { No } \\
\text { No } \\
\text { No } \\
\end{array}$ & $\begin{array}{l}\text { Yes } \\
\text { Yes } \\
\text { Yes } \\
\text { No } \\
\text { No } \\
\text { No } \\
\text { No } \\
\text { No } \\
\end{array}$ & $\begin{array}{l}\text { Yes } \\
\text { No } \\
\text { No } \\
\text { Yes } \\
\text { Yes } \\
\text { No } \\
\text { No } \\
\text { Yes } \\
\end{array}$ & $\begin{array}{l}\text { Yes } \\
\text { Yes } \\
\text { Yes } \\
\text { No } \\
\text { No } \\
\text { No } \\
\text { No } \\
\text { No } \\
\end{array}$ \\
\hline $\begin{array}{l}\text { Number of clusters } \\
\text { Observations } \\
\text { R-squared }\end{array}$ & $\begin{array}{c}(50,23) \\
3,388,061 \\
0.943\end{array}$ & $\begin{array}{c}(50,23) \\
3,388,061 \\
0.943\end{array}$ & $\begin{array}{c}(50,8) \\
1,180,264 \\
0.944 \\
\end{array}$ & $\begin{array}{c}(50,23) \\
3,388,061 \\
0.943 \\
\end{array}$ \\
\hline \multicolumn{5}{|c|}{$\begin{array}{l}\text { Standard Errors clustered at the state level } \\
* * * \mathrm{p}<0.01, * * \mathrm{p}<0.05, * \mathrm{p}<0.1\end{array}$} \\
\hline \multicolumn{5}{|c|}{$\begin{array}{l}\text { Notes: This table reports OLS regressions for two dependent variables; inverse hyperbolic sine } \\
\text { transformation for vacancies in each county i, at date (quarter) t, for occupation o, in columns (1) } \\
\text { through (4). Column (1) reports the result for the dynamic version of our baseline specification. } \\
\text { Analogously, columns (2)-(4) display the dynamic versions of equation }(7),(8) \text {, and (10), } \\
\text { respectively. Note that the log transformation of J } 2 \mathrm{~J} \text { rates do not produce any missing observations } \\
\text { as actual zeros do not exist in the data. We have two-way clustered standard errors for each } \\
\text { regression reported in the table. First set of clusters always refer to the number of states and the } \\
\text { second group indicates the appropriate number of occupations, education groups, or industries. } \\
\text { Regressions include all states, except for Delaware, and include Washington D.C. }\end{array}$} \\
\hline
\end{tabular}


TABLE 13: HETEROGENEITY ANALYSIS - INSPECTING THE MECHANISM THE ROLE OF ZERO VACANCIES

\begin{tabular}{|c|c|c|c|}
\hline & \multicolumn{3}{|c|}{$\begin{array}{c}\text { Dependent Variable: Inverse Hyperbolic Sine } \\
\text { Transformation of Vacancies }\end{array}$} \\
\hline & (1) & (2) & (3) \\
\hline & Subprime & Less Skilled & Routine \\
\hline $\begin{array}{l}\text { Credit check ban } * \text { Affected } * \text { Fraction } \\
\text { subprime }\end{array}$ & $\begin{array}{l}-0.231 * \\
(0.119)\end{array}$ & & \\
\hline Credit check ban *Less than College & & $\begin{array}{l}-0.163 * \\
(0.075)\end{array}$ & \\
\hline Credit check ban * Affected*Routine & & & $\begin{array}{c}-0.117 * * \\
(0.042)\end{array}$ \\
\hline \multicolumn{4}{|l|}{ Credit check ban * Affected } \\
\hline Fixed Effects & & & \\
\hline County x Time FE & Yes & Yes & Yes \\
\hline County x Occupation FE & Yes & No & Yes \\
\hline Occupation $\mathrm{x}$ Time FE & Yes & No & Yes \\
\hline County $\mathrm{x}$ Education FE & No & Yes & No \\
\hline Education $\mathrm{x}$ Time FE & No & Yes & No \\
\hline State $\mathrm{x}$ Time FE & No & No & No \\
\hline State $\mathrm{x}$ Industry FE & No & No & No \\
\hline Industry $\mathrm{x}$ Time FE & No & Yes & No \\
\hline Number of Clusters & $(50,23)$ & $(50,8)$ & $(50,23)$ \\
\hline Observations & $3,386,980$ & $1,180,264$ & $3,388,061$ \\
\hline R-squared & 0.922 & 0.943 & 0.922 \\
\hline
\end{tabular}

Standard errors clustered at the state level

$* * * \mathrm{p}<0.01, * * \mathrm{p}<0.05, * \mathrm{p}<0.1$

Notes: This table reports OLS regressions for two dependent variables; inverse hyperbolic sine transformation for vacancies in each county $i$, at date (quarter) $t$, for occupation $o$, in columns (1) through (3). Column (1) reports the result for the baseline specification exploring the role of heterogeneity by county-level subprime rates expressed in equation (7) in the text. Analogously, columns (2) - (3) display the estimates of the regression coefficients from specifications (8) and (10), respectively. Note that the $\log$ transformation of $\mathrm{J} 2 \mathrm{~J}$ rates do not produce any missing observations as actual zeros do not exist in the data. We have two-way clustered standard errors for each regression reported in the table. First set of clusters always refer to the number of states and the second group indicates the appropriate number of occupations, education groups, or industries. Regressions include all states, except for Delaware, and include Washington D.C. 
TABLE 14: ALTERNATIVE MEASURES OF COUNTY EXPOSURE TO BAN THE ROLE OF ZERO VACANCIES

\begin{tabular}{|c|c|c|c|}
\hline & \multicolumn{3}{|c|}{$\begin{array}{c}\text { Dependent Variable: Inverse Hyperbolic Sine } \\
\text { Transformation of Vacancies }\end{array}$} \\
\hline & (1) & (2) & (3) \\
\hline $\begin{array}{l}\text { Credit check ban * Affected * Fraction subprime } \\
\text { Credit check ban * Affected * Std. Dev. of Risk } \\
\text { Scores } \\
\text { Credit check ban * Affected * 90/10 Ratio of Risk } \\
\text { Scores }\end{array}$ & $\begin{array}{c}-0.024 * \\
(0.012)\end{array}$ & $\begin{array}{l}-0.006 * \\
(0.003)\end{array}$ & $\begin{array}{l}-0.007 * \\
(0.004)\end{array}$ \\
\hline $\begin{array}{l}\text { Fixed Effects } \\
\text { County x Time } \\
\text { Occupation x Time } \\
\text { County x Occupation }\end{array}$ & $\begin{array}{l}\text { Yes } \\
\text { Yes } \\
\text { Yes }\end{array}$ & $\begin{array}{l}\text { Yes } \\
\text { Yes } \\
\text { Yes }\end{array}$ & $\begin{array}{l}\text { Yes } \\
\text { Yes } \\
\text { Yes }\end{array}$ \\
\hline $\begin{array}{l}\text { Number of Clusters } \\
\text { Observations } \\
\text { R-squared }\end{array}$ & $\begin{array}{c}(50,23) \\
3,386,980 \\
0.943 \\
\end{array}$ & $\begin{array}{c}(50,23) \\
3,382,886 \\
0.943 \\
\end{array}$ & $\begin{array}{c}(50,23) \\
3,386,474 \\
0.943\end{array}$ \\
\hline
\end{tabular}

Standard errors clustered by state and occupation.

$* * * \mathrm{p}<0.01, * * \mathrm{p}<0.05, * \mathrm{p}<0.1$

Notes: This table reports OLS regressions for our specification in equation 7 for the inverse hyperbolic sine transformation of the vacancy data, replacing the fraction of subprime residents with different moments of the county-level distribution of risk scores. Each regression coefficient is normalized by the cross-sectional standard deviation of that variable to maintain comparability. Column (1) corresponds to the baseline measure, which is the fraction of residents with a subprime credit score. The second column uses the county-level standard deviation of risk scores as the relevant metric and the third uses the 90/10 ratio of risk scores. Regressions include all states, except for Delaware, and include Washington D.C. 
TABLE 15: OCCUPATIONAL TASK COMPOSITION AND EXPOSURE TO THE BAN THE ROLE OF ZERO VACANCIES

\begin{tabular}{|c|c|c|c|c|}
\hline & \multicolumn{4}{|c|}{$\begin{array}{c}\text { Dependent Variable: Inverse Hyperbolic Sine Transformation } \\
\text { of Vacancies }\end{array}$} \\
\hline & (1) & (2) & (3) & (4) \\
\hline $\begin{array}{l}\text { Credit check ban * Affected * Non-Routine } \\
\text { Credit check ban * Routine Manual } \\
\text { Credit check ban * Routine Cognitive } \\
\text { Credit check ban * Routine } \\
\text { Credit check ban * Affected * Non-Routine*Fraction } \\
\text { subprime } \\
\text { Credit check ban * Routine * Fraction subprime } \\
\text { Credit check ban * Routine Manual * Fraction subprime } \\
\text { Credit check ban * Routine Cognitive * Fraction subprime }\end{array}$ & $\begin{array}{c}-0.017 \\
(0.030) \\
\\
-0.129 * * \\
(0.048)\end{array}$ & $\begin{array}{c}-0.017 \\
(0.030) \\
-0.129 * * \\
(0.047) \\
-0.127 * * \\
(0.049)\end{array}$ & $\begin{array}{c}-0.078 \\
(0.130) \\
-0.579 * * * \\
(0.195)\end{array}$ & $\begin{array}{c}-0.078 \\
(0.130) \\
\\
-0.582 * * * \\
(0.191) \\
-0.574 * * \\
(0.204) \\
\end{array}$ \\
\hline $\begin{array}{l}\text { Fixed Effects } \\
\text { County x Time } \\
\text { Occupation x Time } \\
\text { County x Occupation }\end{array}$ & $\begin{array}{l}\text { Yes } \\
\text { Yes } \\
\text { Yes }\end{array}$ & $\begin{array}{l}\text { Yes } \\
\text { Yes } \\
\text { Yes }\end{array}$ & $\begin{array}{l}\text { Yes } \\
\text { Yes } \\
\text { Yes }\end{array}$ & $\begin{array}{l}\text { Yes } \\
\text { Yes } \\
\text { Yes }\end{array}$ \\
\hline $\begin{array}{l}\text { Number of Clusters } \\
\text { Observations } \\
\text { R-squared }\end{array}$ & $\begin{array}{c}(50,23) \\
3,388,061 \\
0.943 \\
\end{array}$ & $\begin{array}{c}(50,23) \\
3,388,061 \\
0.943 \\
\end{array}$ & $\begin{array}{c}(50,23) \\
3,386,980 \\
0.943 \\
\end{array}$ & $\begin{array}{c}(50,23) \\
3,386,980 \\
0.943 \\
\end{array}$ \\
\hline
\end{tabular}

Standard errors clustered by state and occupation.

$* * * \mathrm{p}<0.01, * * \mathrm{p}<0.05, * \mathrm{p}<0.1$

Notes: This table reports OLS regressions vacancies in each county i, at date (quarter) t, for occupation o, on various different interactions of the exposure to the ban by occupational and county level heterogeneity and the inverse hyperbolic sine transformation of the vacancy data. We have two-way clustered standard errors for each regression reported in the table. First set of clusters always refer to the number of states and the second group indicates the appropriate number of occupations, education groups, or industries. For a detailed description of the mapping between two-digit SOC codes and the routine task content of an occupation, please see section 5.D in the text. Regressions include all states, except for Delaware, and include Washington D.C. 


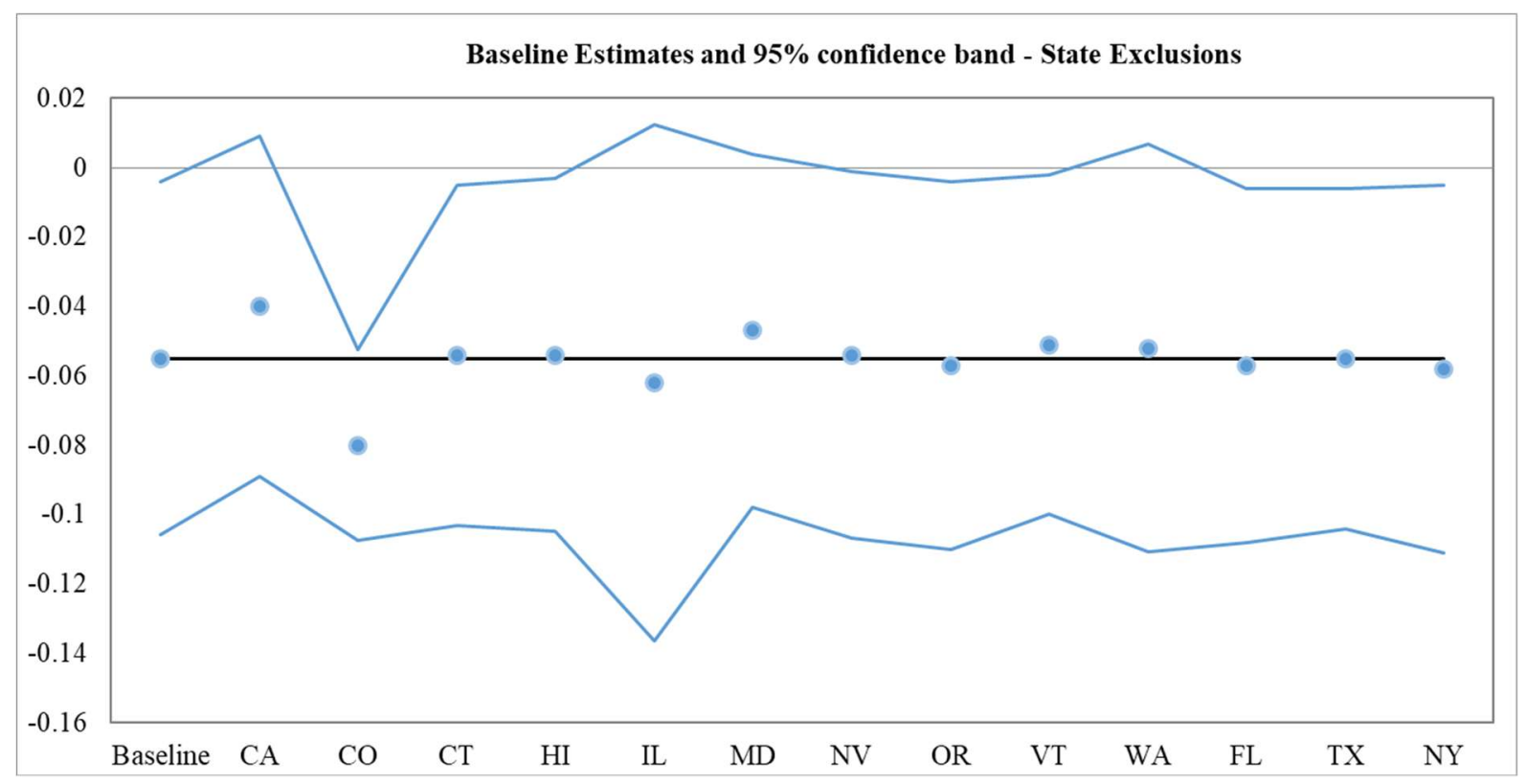

FIGURE 4: BASELINE ESTIMATES WITH STATE EXCLUSIONS

Notes: Figure displays the baseline coefficient estimate from the same specification when we exclude one treated state or one large control state (FL, TX, NY) at a time and the respective $95 \%$ confidence band. The horizontal line indicates the baseline estimate from Table 5. Standard errors clustered by state and occupation. Regressions include all states, except for Delaware, and include Washington D.C. 
TABLE 16: ROBUSTNESS for CREDIT CHEK BAN EFFECTS - PLACEBO TESTS

\begin{tabular}{|c|c|c|c|c|}
\hline & $\begin{array}{c}\log \text { (Earnings) } \\
(1) \\
\end{array}$ & $\begin{array}{l}\text { Emp. Share } \\
\text { for New } \\
\text { Firms } \\
(2) \\
\end{array}$ & $\begin{array}{l}\text { Log(Avg. } \\
\text { Deposits) } \\
(3) \\
\end{array}$ & $\begin{array}{c}\log (\text { Total } \\
\text { Deposits) } \\
(4) \\
\end{array}$ \\
\hline $\begin{array}{l}\text { Credit check ban* } \\
\text { Affected } \\
\text { Credit check ban }\end{array}$ & $\begin{array}{l}-0.008 \\
(0.012)\end{array}$ & $\begin{array}{c}-0.183 * * \\
(0.074)\end{array}$ & $\begin{array}{c}0.006 \\
(0.017)\end{array}$ & $\begin{array}{c}0.002 \\
(0.021)\end{array}$ \\
\hline $\begin{array}{l}\text { Fixed Effects } \\
\text { County x Time } \\
\text { County x industry } \\
\text { Industry x Time } \\
\text { County } \\
\text { Time } \\
\end{array}$ & $\begin{array}{l}\text { Yes } \\
\text { Yes } \\
\text { Yes } \\
\text { No } \\
\text { No }\end{array}$ & $\begin{array}{l}\text { Yes } \\
\text { Yes } \\
\text { Yes } \\
\text { No } \\
\text { No } \\
\end{array}$ & $\begin{array}{l}\text { No } \\
\text { No } \\
\text { No } \\
\text { Yes } \\
\text { Yes }\end{array}$ & $\begin{array}{l}\text { No } \\
\text { No } \\
\text { No } \\
\text { Yes } \\
\text { Yes }\end{array}$ \\
\hline $\begin{array}{l}\text { Number of Clusters } \\
\text { Observations } \\
\text { R-squared }\end{array}$ & $\begin{array}{c}(50,19) \\
1,811,481 \\
0.945 \\
\end{array}$ & $\begin{array}{c}(50,19) \\
1,811,481 \\
0.374 \\
\end{array}$ & $\begin{array}{c}50 \\
38,422 \\
0.932 \\
\end{array}$ & $\begin{array}{c}50 \\
38,422 \\
0.993 \\
\end{array}$ \\
\hline \multicolumn{5}{|c|}{$\begin{array}{l}\text { Standard errors clustered two-way in (1) and (2), by state and industry. } \\
* * * \mathrm{p}<0.01, * * \mathrm{p}<0.05, * \mathrm{p}<0.1 \\
\text { Notes: Columns (1)-(2) use county by industry data and a similar triple-diff specification we } \\
\text { use in our baseline for vacancies. Column (1) is in log points, so }-0.003 \text { corresponds to }-0.3 \% \text {. } \\
\text { Column (2) is in percent, so }-0.18 \text { represents a } 15 \text { basis point decline. Columns (3) - (4) present } \\
\text { difference-in-difference estimates of the effect of employer credit check bans on bank deposits, } \\
\text { which are at the county level with annual observations. Earnings and employment shares for } \\
\text { new firms are measured quarterly from the QWI. Deposits are measured annually from the } \\
\text { FDIC. }\end{array}$} \\
\hline
\end{tabular}




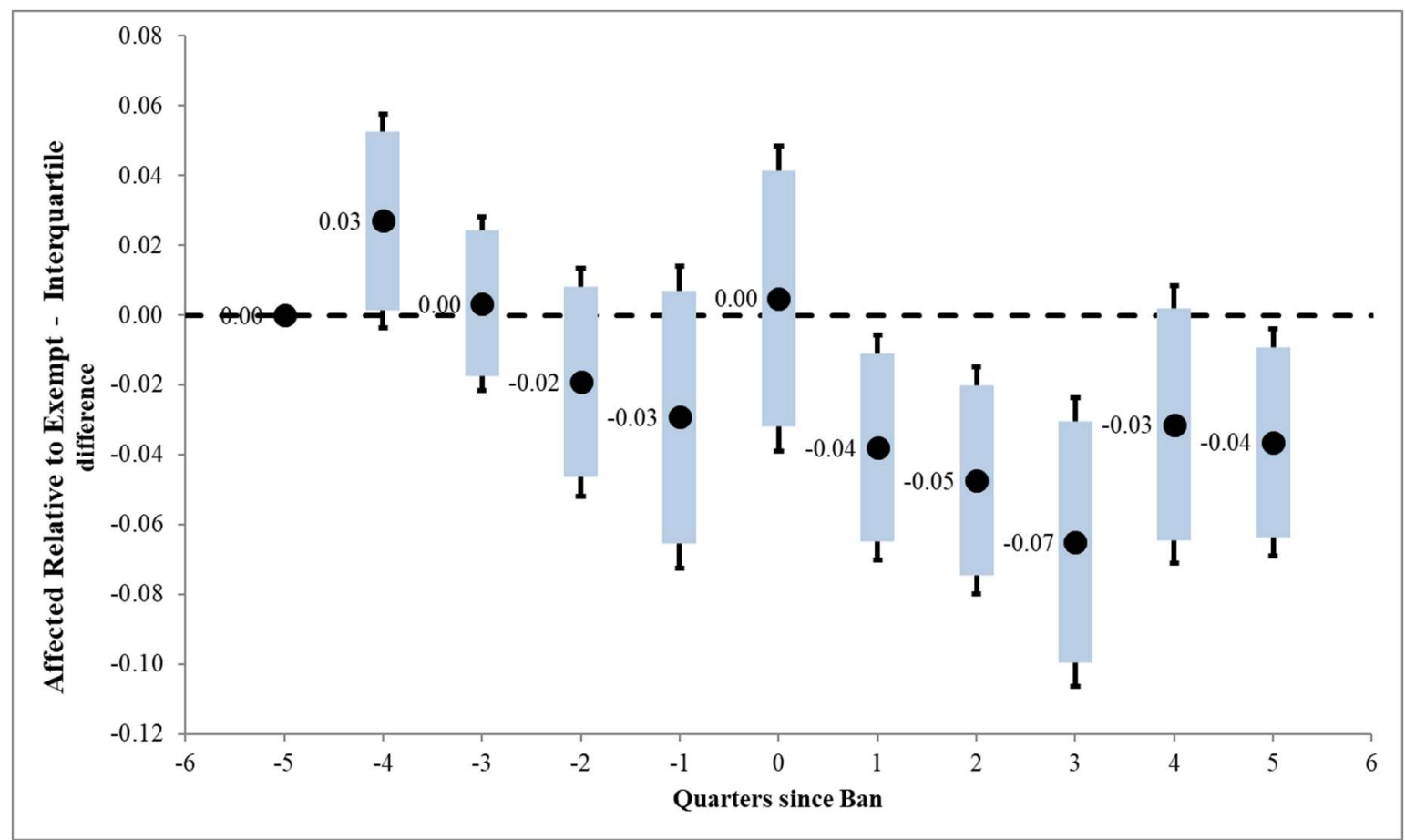

Figure 5: DynAmics OF VACANCIES By COUNTY SubPrime RATE

Notes: Figure displays estimates of $\beta_{j}$ from regression equation (7) in the text, scaled by the interquartile range of county-level subprime rates. Solid circles correspond to point estimates, while solid box error bars correspond to $90 \%$ confidence intervals and capped lines correspond to $95 \%$ confidence intervals. Quarters -5 and 5 correspond to average in periods more than one year before and after the ban and all differences are relative to periods more than one year before the ban ( -5 is zero by construction). Regressions include all states, except for Delaware, and include Washington D.C. 


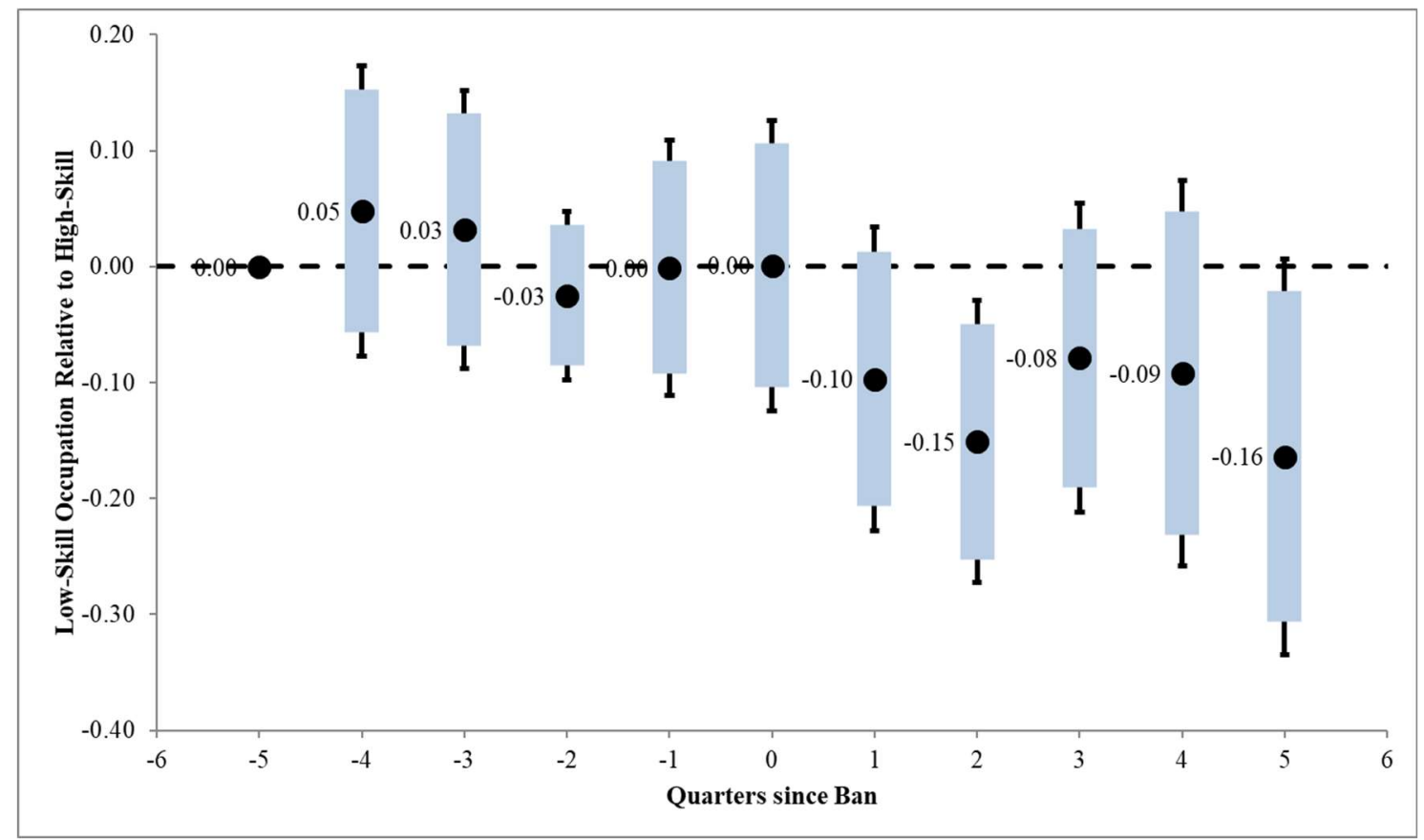

FigURE 6: DyNAMICS OF VACANCIES By OCCUPATIONAL SKILL

Notes: Figure displays estimates of $\beta_{j}$ from regression equation (8) in the text. Solid circles correspond to point estimates, while solid box error bars correspond to $90 \%$ confidence intervals and capped lines correspond to $95 \%$ confidence intervals. Quarters -5 and 5 correspond to average in periods more than one year before and after the ban and all differences are relative to periods more than one year before the ban $(-5$ is zero by construction). Regressions include all states, except for Delaware, and include Washington D.C. 


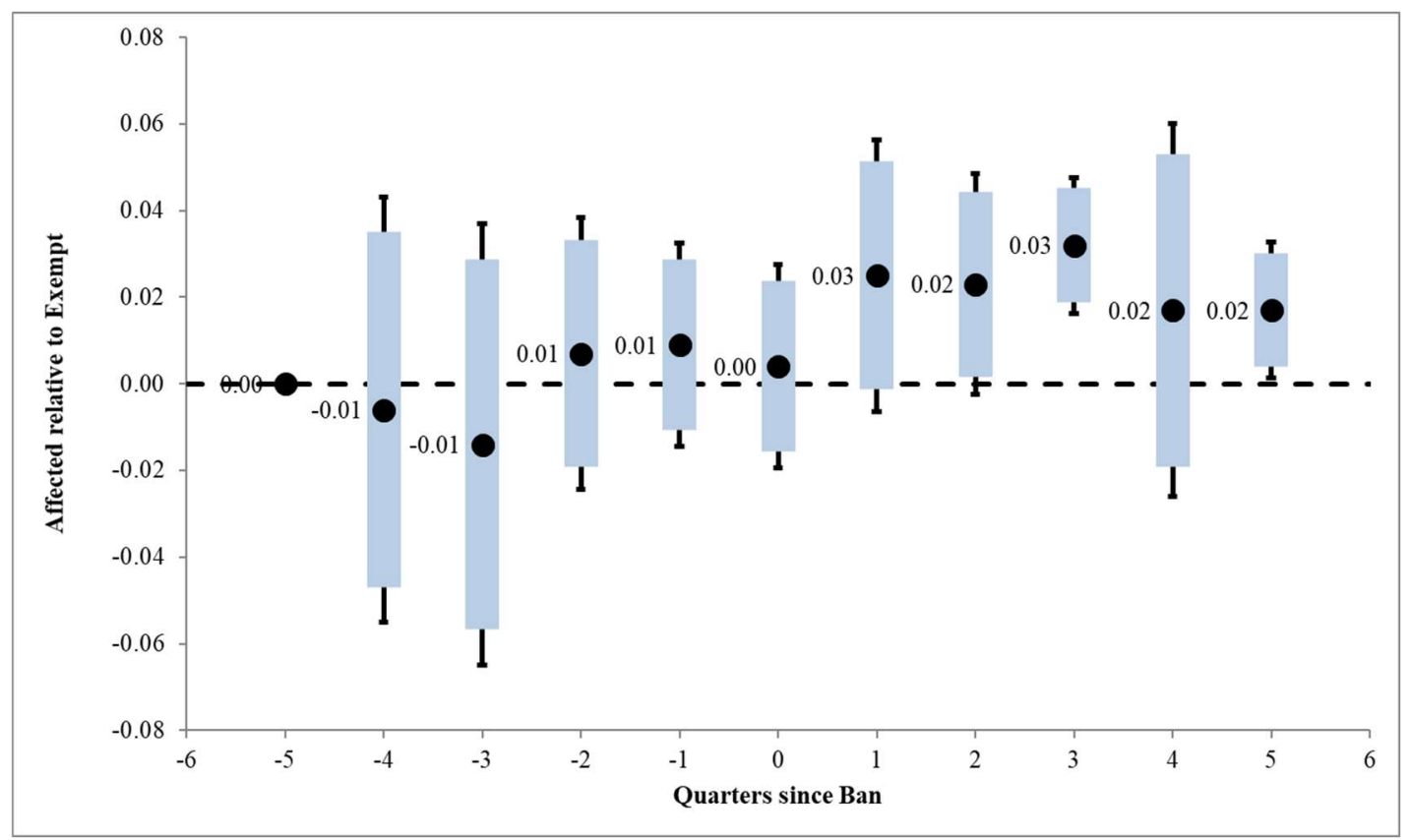

FiguRE 7: DyNAMics OF JoB-TO-Job FLOW IN AFFECTEd RELATIVE to EXEMPT INDUSTRIES

Notes: Figure displays estimates of $\beta_{j}$ from regression equation (10) in the text. Solid circles correspond to point estimates, while solid box error bars correspond to $90 \%$ confidence intervals and capped lines correspond to $95 \%$ confidence intervals. Quarters -5 and 5 correspond to average in periods more than one year before and after the ban and all differences are relative to periods more than one year before the ban ( -5 is zero by construction). Regressions include all states, except for Delaware, and include Washington D.C. 


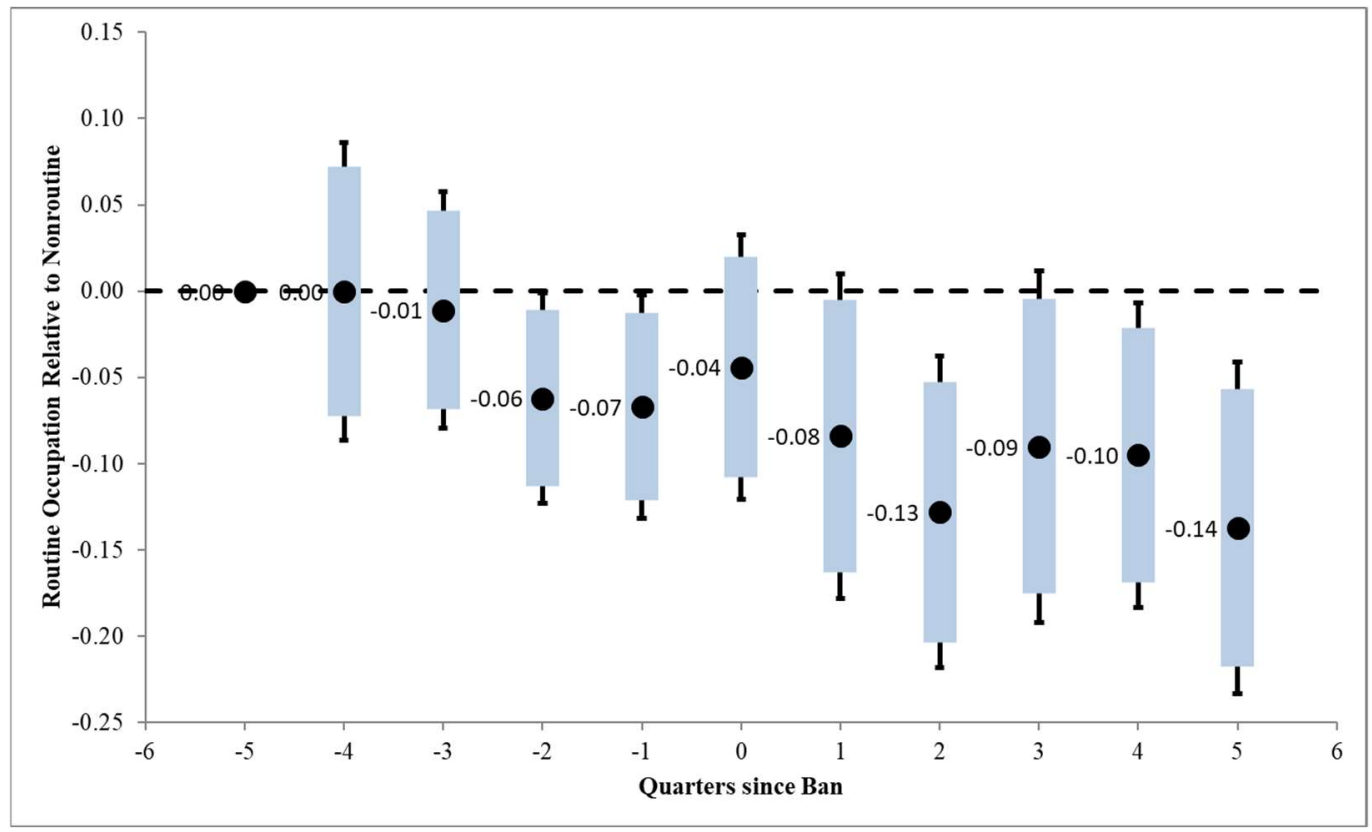

FigURE 8: DYNAMiCS OF VACANCIES BY TASK TYPE

Notes: Figure displays estimates of $\beta_{j}$ from regression equation (9) in the text. Solid circles correspond to point estimates, while solid box error bars correspond to $90 \%$ confidence intervals and capped lines correspond to $95 \%$ confidence intervals. Quarters -5 and 5 correspond to average in periods more than one year before and after the ban and all differences are relative to periods more than one year before the ban $(-5$ is zero by construction). Regressions include all states, except for Delaware, and include Washington D.C. 